\title{
Labores y vida urbana de los esclavos de particulares y del rey en Cartagena de Indias, 1750-1810
}

\author{
Labors and urban life of private slaves and of the king in Cartagena \\ de Indias, 1750-1810
}

\section{Trabalho e vida urbana de escravos privados e do rei em Cartagena de Indias, 1750-1810}

Para citaciones: Solano, S., Vanegas, M., \& Hernández, D. (2021). Labores y vida urbana de los esclavos de particulares y del rey en Cartagena de Indias, 1750-1810. El Taller de la Historia, 13(1), 25-58.

Recibido: noviembre 2020

Aprobado: abril 2021

Editor: Sergio Paolo Solano. Universidad de Cartagena-Colombia.

Copyright: $\odot$ 2021. Solano, S., Vanegas, M., \& Hernández, D. Este es un artículo de acceso abierto, distribuido bajo los términos de la licencia https://creativecommons.org/licenses/by-nc$\mathrm{sa} / 4.0 /$ la cual permite el uso sin restricciones, distribución y reproducción en cualquier medio, siempre y cuando que el original, el autor y la fuente sean acreditados.

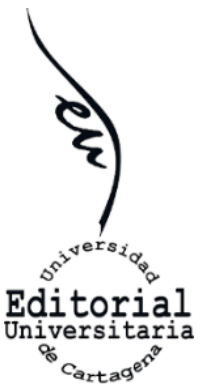

A la memoria de los colegas Carlos Costa Molina, Isaac Kalil Bermúdez, Alberto Montiel del Río y Germán Steffens Buelvas, jóvenes historiadores egresados de la Universidad de Cartagena que partieron en medio de la pandemia que nos asola

\section{RESUMEN}

Este artículo analiza la dinámica de la esclavitud en Cartagena de Indias durante los años comprendidos entre 1750 y 1810. En el marco de las características demográficas, económicas, militares y sociales de la ciudad, estudia la distribución de los esclavos de propiedad de particulares entre distintos sectores sociales (elite, capas medias y bajos), las ocupaciones a que se les destinaban, sus distribuciones en el área urbana y el uso que hacían de los espacios públicos. También analiza la presencia de un contingente de esclavos propiedad de la corona y sus trabajos en las fortificaciones. Muestra que, durante el tiempo estudiado, sectores de esclavos empezaron a gozar de algunos niveles de autonomía con relación a sus amos (ocupaciones diversas, trabajo estipendiario, vivienda aparte) y que la esclavitud en la ciudad se caracterizó por una tendencia numérica decreciente, como resultado de la combinación de varias circunstancias, entre ellas el crecimiento de la población libre.

Palabras clave: Esclavos; espacio urbano; Cartagena de Indias; ocupaciones. 
presence of a contingent of slaves owned by the crown, and their work in the fortifications. It shows that, during the time studied, sectors of slaves began to enjoy some levels of autonomy in relation to their masters (diverse occupations, stipendial work, separate housing) and that slavery in the city was characterized by a decreasing numerical trend, as a result of a combination of several circumstances, including the growth of the free population.

Keywords: Slaves; urban space; Cartagena de Indias; occupations.

\section{RESUMO}

Este artigo analisa a dinâmica da escravidão em Cartagena de Indias durante os anos entre 1750 e 1810. No âmbito das características demográficas, econômicas, militares e sociais da cidade, estuda a distribuição de escravos privados entre diferentes setores sociais (elite, médio e inferior), as ocupações a que foram destinados, suas distribuições na área urbana e o uso que fizeram dos espaços públicos. Ele também analisa a presença de um contingente de escravos de propriedade da coroa, seu trabalho nas fortificações. Mostra que, durante o tempo estudado, setores de escravos passaram a desfrutar de alguns níveis de autonomia em relação aos seus mestres (diversas ocupações, trabalho salarial, moradia separada) e que a escravidão na cidade foi caracterizada por uma tendência numérica decrescente, como resultado da combinação de várias circunstâncias, incluindo o crescimento da população livre.

Palavras-chave: Escravos; espaço urbano; Cartagena de Índias; ocupações.

\section{Presentación}

A una primera fase de investigaciones sobre la esclavitud como una institución de naturaleza económica cuyas variables centrales fueron la trata negrera, los precios, los frentes de trabajo en que se les empleaba (minas y haciendas) y los maltratos que padecían, luego sobrevinieron estudios relacionados con el cimarronaje y la manumisión y abolición final de la esclavitud. Orientados en la perspectiva de la historia social y en menor medida de la cultural estos temas han derivado en el análisis de las formas de resistencia individuales de los esclavos, y a sus roles diferenciados en la sociedad. El uso que hacían de algunas herramientas legales del XVIII ha sido clave en el desarrollo de estas investigaciones, y han colocado en el centro de las reflexiones su vida material, social y cultural ${ }^{4}$. Resultado promisorio de estos nuevos enfoques es el análisis de los campos relacionales en que desenvolvían sus vidas cotidianas. Aunque Cartagena de Indias no ha sido

\footnotetext{
4 Aline Helg, "Esclavos y libres de color, negros y mulatos en la investigación y la historia de Colombia". Revista Iberoamericana, LXV, (188-189), 1999: 697-712; "Oralidad y escritura en la historiografía de los esclavos afrodescendientes”, en Graciela Maglia y Armin Schwegler (eds.), Palenque. Colombia: oralidad, identidad y resistencia, Bogotá, Universidad Javeriana, 2011, pp. 85-106; María C. Navarrete, Génesis y desarrollo de la esclavitud en Colombia, Cali, Universidad del Valle, 2005; Alfonso Múnera, Fronteras imaginadas, Bogotá, Planeta, 2005, pp. 193-225; Guido Barona, “Ausencia y presencia del 'negro' en la historia de Colombia”. Memoria y Sociedad, 1, (1), 2014: 77-105; Dolcey Romero, Rosario Márquez y Manuel García, Manumisión y abolición de la esclavitud en el Caribe colombiano 1812-1852, Barranquilla, Universidad Simón Bolívar, 2018, pp. 9-35.
} 
ajena a estas nuevas preocupaciones historiográficas, muchos aspectos continúan pendientes, tales como los trabajos desempeñados por los esclavos, las diferencias entre los de propiedad de particulares y los del rey en el período colonial tardío, la participación en la demografía y la sociedad de la ciudad, como también realizar comparaciones con los negros y mulatos libres de los estratos bajos de la sociedad. Esto último, es de relativa importancia dada las particularidades de la crisis interna de la esclavitud y el alto volumen de población negra libre en la ciudad desde la segunda mitad del siglo XVIII.

En ese contexto historiográfico descrito en rasgos generales, este artículo analiza algunos aspectos de la vida de los esclavos en Cartagena de Indias durante la segunda mitad del siglo XVIII. Al igual que en el resto de ciudades hispanoamericanas, en aquella plaza fuerte la cercanía con los amos situó a los esclavos en el ámbito privado, pero también en los espacios públicos y en interacciones con otros grupos sociales. Existió cierta flexibilidad en sus relaciones con los amos, y vivir en la ciudad les representó contar con espacios de circulación y de mediación: las calles, las tabernas, las pulperías, los mercados y plazas y las playas. Muchos eran destinados a salir a ganarse un jornal ("tributo jornal") en ventas callejeras", lo que les permitió, además de vincularse al mercado laboral a través del desempeño de diversas actividades, tener cierto control sobre sus trabajos y sus tiempos ${ }^{6}$. No pocos se capacitaron en ciertos oficios, lo que influyó, tanto en sus precios de compraventas, como en sus autovaloraciones.

Argumentamos que el descenso del cimarronaje (debido a la destrucción de los palenques o las negociaciones con las autoridades coloniales), con relación al vivido en el siglo $\mathrm{XVII}^{7}$, aunado a la crisis de la ciudad durante la primera mitad de ese siglo y la creciente flexibilidad de los esclavos para moverse en diversos trabajos, fueron factores que atravesaron el mundo de estos, en sus relaciones con los amos, las instituciones coloniales y con el espacio urbano. Aunque durante el XVIII los esclavos continuaron fugándose, los palenques, que habían florecido durante los dos siglos anteriores ${ }^{8}$, descendieron en cantidad durante los años que estudiamos, debido a las destrucciones que padecieron, y porque los que sobrevivieron negociaron con las autoridades coloniales ${ }^{9}$. Todo parece indicar que se amplió

\footnotetext{
${ }^{5}$ Carmen Bernard, Negros esclavos y libres en las ciudades hispanoamericanas, Madrid, Fundación Larramendi/Mapfre 2005, p. 5; M. Navarrete, Génesis y desarrollo de la esclavitud en Colombia.

${ }^{6}$ Eduardo Saguier, "La naturaleza estipendiaria de la esclavitud urbana colonial. El caso de Buenos Aires en el siglo XVIII". Estudos Ibero-Americanos, 15, (2), 1989: 315-325; Roland Anrup y María E. Chaves, "La "plebe" en una sociedad de "todos los colores". La construcción de un imaginario social y político en la colonia tardía en Cartagena y Guayaquil". Cahiers du Monde Hispanique et Luso-Brésilien, 84, 2005: 93-126.

${ }^{7}$ M. Navarrete, Génesis y desarrollo de la esclavitud en Colombia; Jane Landers, "The African landscape of 17th century Cartagena and its hinterlands", in Jorge Cañizares-Ezguerra, James Sidbury and Matt D. Childs (eds.), The Black Urban Atlantic in the Age of the Slave Trade The Early Modern Americas, Philadelphia, University of Pennsylvania Press, 2013, pp. 147-162; Aline Helg, ¡Nunca más esclavos!: una historia comparada de los esclavos que se liberaron en las Américas, Bogotá, Banco de la República/FCE, 2018, pp. 63-77.

${ }^{8}$ M. Navarrete, Génesis y desarrollo de la esclavitud en Colombia; J. Landers, "The African landscape of 17 th century Cartagena and its hinterlands", pp. 147-162; Dolcey Romero, Los afroatlanticenses; "Los acuerdos y la idealización del palenque en la provincia de Cartagena: el caso del Totumo (1714-1767)". Historia Caribe, 15 (37), 2020: 215-247; (2021). "Cimarrones y palenques en el actual departamento del Atlántico. El caso de tabacal: resistencias y exclusión". Amauta, 19, (37), 2021: 1-23.

${ }^{9}$ María del C. Borrego, Palenques de negros en Cartagena de Indias a fines del siglo XVII, Sevilla, EEHA/CSIC, 1973; Anthony McFarlane, "Cimarrones y palenques en Colombia siglo XVIII". Historia y Espacio, 14, 1991: 53-78; Anthony
} 
el arco de sus iniciativas individuales para intentar aminorar un poco sus adversas condiciones de vida. Esto se constata tanto en los aspectos que privilegian las investigaciones (manumisiones, solicitud de cambio de amos por maltratos, demanda por incumplimiento de los herederos de la voluntad testamentaria de quien les concedía la libertad ${ }^{10}$ ), como en el desarrollo de relaciones con los amos, con los oficios, con el espacio urbano y con las instituciones que son indicios de que algo estaba cambiando para ellos.

Para adelantar el análisis diferenciamos a los esclavos de particulares y los de propiedad de la corona. Los primeros pertenecían a distintos propietarios y en alta proporción eran criollos. Entre los amos estuvieron los que tenían capacidad para ostentar prestancia, y también los propietarios de sectores intermedios y pobres que enviaban a sus esclavos a ganar un jornal. Los esclavos de la corona formaron contingentes significativos en las ciudades costeras ligadas a la defensa militar del imperio español, destinados, en la mayoría de los casos, a los más rudos menesteres de construcción y reparación de sistemas de fortificaciones. Aunque ambos grupos compartían muchos aspectos vitales, también tenían sus diferencias.

Una de esta tenía que ver con los oficios y formas de vida. Los esclavos de particulares, además de encargarse de los oficios domésticos ${ }^{11}$, también eran dedicados a diversas ocupaciones por fuera de esos espacios, lo que les permitió intensificar sus vínculos con sectores de negros y mulatos libres que se desempeñaban en parecidos menesteres. Sobre los esclavos de la corona existen pocos estudios ${ }^{12}$. En su mayoría eran bozales, se les destinaban a los trabajos en las fortificaciones de la ciudad y en la Real Fábrica de Aguardiente. Sobre estos se ejercían formas de control distintas a las aplicadas los de propiedad particular, lo mismo que la asistencia social, como también sus relaciones con el espacio urbano. Al no tener amos particulares, a la mayoría de los esclavos del rey se les dio por apellidos los de sus castas. Y su criollización estaba mediada por sus traslados a otras ciudades fortificadas que requirieran de sus trabajos, como era el caso de Portobelo, Panamá y La Habana.

\footnotetext{
McFarlane, "Autoridad y poder en Cartagena de Indias: la herencia de los Austrias", en Haroldo Calvo y Adolfo Meisel (eds.), Cartagena de Indias en el siglo XVIII, Cartagena, Banco de la República, 2005, pp. 221-259; María C. Navarrete, San Basilio de Palenque, memoria y tradición. Surgimiento y avatares de las gestas cimarronas en el Caribe colombiano, Cali, Universidad del Valle, 2008; D. Romero, "Los acuerdos y la idealización del palenque en la provincia de Cartagena", 215-247.

${ }^{10}$ Loredana Giolitto, "Esclavitud y libertad en Cartagena de Indias. Reflexiones en torno a un caso de manumisión a finales del período colonial”. Fronteras de la Historia, 8, 2003: 63-91; Dolcey Romero, Los afroatlanticenses: esclavización, resistencia y abolición, Barranquilla, Universidad Simón Bolívar, 2009, pp. 97-120; Fanny Rangel, Entre la libertad y la esclavitud: "Dominga Pérez en el litigio por su libertad y la de sus hijas, Cartagena, trabajo de grado en HistoriaUniversidad de Cartagena 2011; Sandra Taborda, La esclavitud en Cartagena en la segunda mitad del siglo XVIII: entre el maltrato y la resistencia, Cartagena, trabajo de grado en Historia-Universidad de Cartagena 2013; Dianis Hernández, Esclavos y esclavas en el acceso a la libertad en Cartagena y Mompox 1759-1794: proporciones y dinámicas, Cartagena, trabajo de grado en Historia-Universidad de Cartagena, 2014; David Sánchez, La esclavitud y sus conceptos en Cartagena de Indias (1789-1797), Cartagena, trabajo de grado en Historia-Universidad de Cartagena, 2017; Fanny Avendaño, Vías legales usadas por los esclavos en la colonia para pedir la libertad. Un estudio de casos, 1791-1803, Cartagena, trabajo de grado en Historia-Universidad de Cartagena, 2017.

${ }^{11}$ Jaime Jaramillo Uribe, "Esclavos y señores en la sociedad colombiana del siglo XVIII". Anuario Colombiano de Historia Social y de la Cultura, 1, 1963: 3-62; Jorge Palacios, La trata de negros por Cartagena de Indias: 1650-1750, Tunja, UPTC, 1973; Ildefonso Gutiérrez, "El comercio y mercado de negros esclavos en Cartagena de Indias (1533-1850)". Quinto Centenario, 12, 1987: 187-210.

${ }^{12}$ Francisco Pérez, "Modo de vida de esclavos y forzados en las fortificaciones de Cuba: siglo XVIII". Anuario de Estudios Americanos, 47, 1990: 241-257.
} 


\section{Los esclavos de particulares}

Durante la segunda mitad del siglo XVIII la vida económica y social de Cartagena se dinamizó en varias direcciones. La seguridad brindada por la renovación de los sistemas defensivos y las oportunidades de trabajo atrajeron migraciones y trabajadores de otros lugares creciendo el número de habitantes de la ciudad. Esas obras demandaron grandes inversiones ${ }^{13}$ y estimularon el desarrollo de las labores de los artesanos y dieron empleo a una significativa cantidad de jornaleros ${ }^{14}$. En el apostadero de la marina, las fortificaciones y la maestranza de la artillería se consolidaron y crecieron núcleos de maestros artesanos con ingresos que podían hasta quintuplicar los de los jornaleros ${ }^{15}$. La Real Fábrica de Cigarros, que funcionó entre 1778 y 1805, demandó trabajo continuo de un promedio diario de casi 200 mujeres ${ }^{16}$. Varios sectores sociales se convirtieron en proveedores de materias primas, permitiendo que se distribuyeran entre diferentes franjas de la población los dineros destinados a las defensas ${ }^{17}$.

La expedición del estatuto de libre comercio de 1776 permitió la llegada de nuevos comerciantes lo que redundó en la renovación de la elite ${ }^{18}$. El crecimiento demográfico y los mestizajes y manumisiones originaron en el incremento de las cantidades de negros y pardos libres ${ }^{19}$. Aumento de la población y el incremento del número de libres ofrecieron la posibilidad de empezar a contar con la mano de obra que requerían los trabajos en los sistemas defensivos, y el incremento de la franja de la población que vivía de los jornales estimularon la ampliación de la demanda de bienes y abrieron espacios para el mediano y pequeño comercio expresado en el crecimiento del número de tiendas de mercaderías y de pulperías ${ }^{20}$. La apertura del Colegio Seminario San Carlos Borromeo en 1778 brindó oportunidades para que jóvenes de sectores medios de blancos y pardos acomodados económicamente ejercieran el sacerdocio ${ }^{21}$. Creció la cantidad de procuradores de número que ofrecían sus servicios a quienes entablaban pleitos judiciales, como también aumentó el número de escribanos y

\footnotetext{
13 José Serrano, Fortificaciones y tropas. El gasto militar en Tierra Firme, 1700-1788, Bogotá, El Áncora Eds., 2006; Adolfo Meisel, "El situado de Cartagena de Indias a fines del Siglo de las Luces", en Carlos Marichal y Johanna von Grafenstein (coords.), El secreto del imperio español: los situados coloniales en el siglo XVIII, México, COLMEX/Instituto Mora, 2012, pp. 193-211.

${ }^{14}$ Sergio Paolo Solano, "Trabajadores, jornales, carestía y crisis política en Cartagena de Indias, 1750-1810”. Historia, 51, (II), 2018: 549-588.

${ }^{15}$ Sergio Paolo Solano, "Artesanos, jornaleros y formas concentradas de trabajo: el Apostadero de la Marina de Cartagena de Indias (Nuevo Reino de Granada) en el tránsito entre los siglos XVIII y XIX”. Theomai, 31, 2015: 79-115; "Trabajadores, jornales, carestía y crisis política en Cartagena de Indias", 549-588.

${ }^{16}$ Sergio Paolo Solano, Muriel Vanegas Beltrán y Johan Torres, "Tabaco y trabajo femenino. La Real Fábrica de Cigarros de Cartagena de Indias, 1778-1805". Memorias, 17, (45), 2021. Próximo a publicarse.

${ }^{17}$ Sergio Paolo Solano, "Gasto fiscal e inversiones en mano de obra libre en Hispanoamérica. el caso de Cartagena de Indias (1750-1810)". Anuario de Historia Regional y de las Fronteras, 24, (2), 2019: 195-232

${ }^{18}$ María T. Ripoll, La elite en Cartagena y su tránsito a la República. Revolución política sin renovación social, Bogotá, Universidad de los Andes, 2006; Muriel Vanegas Beltrán, Sergio Paolo Solano y Roicer Flórez, "Elites y poder colonial: comerciantes y cabildo en Cartagena de Indias, 1750-1810". Memorias, 16, (42), 2020: 44-75.

${ }^{19}$ Aline Helg, "Sociedad y raza en Cartagena a fines del siglo XVIII", en H. Calvo y A. Meisel, Cartagena de Indias en el siglo XVIII, pp. 319-364.

${ }^{20}$ Muriel Vanegas Beltrán, Sergio Paolo Solano y Maribel de la Cruz, "El pequeño comercio en Cartagena de Indias: las tiendas de pulperías, 1770-1810". Amauta, 19, (37), 2021: 1-23.

${ }^{21}$ Sergio Paolo Solano, Muriel Vanegas Beltrán y Roicer Flórez Bolívar, "Sociedad, raza, educación y movilidad social: Colegio Real y Seminario Conciliar San Carlos Borromeo y Sacerdotes en Cartagena de Indias (1750-1810)". Historia, 53, (II), 2020: 631-660.
} 
amanuenses que laboraban en las instituciones ordinarias, militares y eclesiásticas y para personas del común ${ }^{22}$. La reforma militar borbónica facilitó la formación de una oficialidad de milicias de pardos y morenos con fuero militar ${ }^{23}$, la que luchó al interior de las compañías milicianas para disminuir las exclusiones y la distancia con relación a la oficialidad media blanca $^{24}$. La diversificación del mediano y pequeño comercio, la militarización de la sociedad y el encuadramiento institucional de sectores de la población dieron oportunidad para que franjas de libres de color pasaran a formar parte de los sectores medios, y se abrieron algunos espacios para la movilidad política institucional ${ }^{25}$.

Pero durante el tránsito del siglo XVIII al XIX, las condiciones de vida se volvieron desfavorables para los sectores medios y bajos de la ciudad. Los problemas que afrontó el Estado fiscal militar imperial ${ }^{26}$ restringieron el envío de los dineros para las defensas, lo que, a su vez, afectó la contratación de trabajadores, y los salarios se estancaron y hasta retrocedieron. A estas dificultades se aunaron crisis de producción agropecuaria en las áreas que abastecían a Cartagena, la especulación y el desvío de las provisiones hacía otros mercados, y se dispararon los precios de los artículos de primera necesidad. En 1805 cerró la Real Fábrica de Cigarros que ocupaba a 200 operarias $^{27}$.

En estos contextos económicos y sociales contrastantes, la representación numérica del total de esclavos en la población de la ciudad tuvo distintos comportamientos. La tabla 1 registra el total de esclavos y su participación porcentual en los habitantes de la ciudad desde el último tercio del siglo XVII hasta comienzos del XIX. La cifra de 1751 indica un descenso del número total, lo que en buena medida se debió a los efectos del asalto de 1697, y luego con el asedio por la armada inglesa en 1741. Y luego, entre 1751 y 1777 se incrementó el número en la ciudad, en lo que influyó el hecho de que la corona introdujo un contingente para que laborara en la reparación y construcción de fortificaciones. El decrecimiento que se registra luego de 1777, tanto en cifras absolutas como con relación al total de los habitantes de Cartagena, se debió, entre otras razones, al mayor crecimiento de la población libre, la crisis

\footnotetext{
${ }^{22}$ Archivo General de la Nación-Colombia (AGN), Sección Colonia (SC), fondo Historia Civil, t.22, doc.20, f.684v.; AGN, SC, fondo Empleados Públicos-Bolívar, t.16, fs.452r.-467r.; t.9, fs.849-904; t.30, f.602r.; AGN, SC, fondo Miscelánea, t.31, doc.8, fs.148r.-154v., doc.39, fs.1014r.-1015v.; AGN, SC, fondo Censos Varios Departamentos (CVD), t.6, doc.36, fs.259r.260v.; doc.72, fs.615r.-619v.; AGN, SC, fondo Milicias y Marina (MM), t.48, doc.32, fs.725r.-734r.

${ }^{23}$ Juan Marchena, La institución militar de Cartagena de Indias 1700-1810, Sevilla, EEHA/CSIC, 1982; Allan Kuethe, Reforma militar y sociedad en la Nueva Granada, 1773-1808, Bogotá, Banco de la República, 1993.

${ }^{24}$ Sergio Paolo Solano, "Artesanos de color y milicias en el Caribe continental hispánico. Reflexiones acerca de la cultura política de los libres de color a finales del dominio colonial", en Alcides Beretta Curi (coord.), Artesanos de dos mundos: diálogos y problemas de investigación, Montevideo, Universidad de la República, 2019, pp. 7-53.

${ }^{25}$ Sergio Paolo Solano, "Pedro Romero, el artesano: trabajo, raza y diferenciación social en Cartagena de Indias a finales del dominio colonial". Historia Crítica, 61, 2016: 151-170; "Artesanos, bellas artes, raza y política en Cartagena de Indias (Nuevo Reino de Granada) a finales de la colonia", en Alcides Beretta Curi (coord.), Inmigración europea, artesanado y orígenes de la industria en América Latina, Montevideo, Universidad de la República, 2016, pp. 113-142.

${ }^{26}$ Rafael Torres, El precio de la guerra. El Estado fiscal militar de Carlos III (1779-1783), Madrid, Marcial Pons, 2013; Carlos Marichal, La bancarrota del virreinato. Nueva España y las finanzas del imperio español (1780-1810), México, FCE/COLMEX, 1999; A. Meisel, "El situado de Cartagena de Indias a fines del Siglo de las Luces", pp. 193-211.

${ }^{27}$ S. P. Solano, M. Vanegas Beltrán y J. Torres, "Tabaco y trabajo femenino"; Sergio Paolo Solano, "Trabajadores, salarios y precios en Cartagena de Indias, 1750-1810. Una aproximación al estudio del mundo laboral de la plaza fuerte". Boletín de Historia y Antigüedades, CVI, (869), 2029: 110-122; "El costo social de la república: los trabajadores de los sistemas defensivos de Cartagena de Indias, 1750-1850". Historia y Memoria, 18, 2019: 243-287.
} 
económica de la ciudad y la saca de esclavos para destinarlos a las haciendas. Las cifras de comienzos del XIX son de descenso para no volver a recuperarse hasta la abolición definitiva de la esclavitud en 1851.

Tabla 1: Participación de los esclavos en el total de habitantes de Cartagena, 16631805

\begin{tabular}{cccccccc}
\hline Años & $\begin{array}{c}\text { Total } \\
\text { habitantes }\end{array}$ & Esclavos & $\begin{array}{c}\text { L } \\
\text { esclavos }\end{array}$ & $\begin{array}{c}\text { de } \\
\text { todos } \\
\text { los } \\
\text { colores }\end{array}$ & $\begin{array}{c}\text { \% libres } \\
\text { de todos } \\
\text { los } \\
\text { colores }\end{array}$ & Blancos & $\begin{array}{c}\% \\
\text { blancos }\end{array}$ \\
\hline 1663 & 7.335 & 2.704 & 36,9 & 2.211 & 30,1 & 4.505 & 25,9 \\
\hline 1751 & 7.856 & 1.602 & 20,4 & & & & \\
\hline 1777 & 13.690 & 2.584 & 18,9 & 9.415 & 54,1 & 4.505 & 25,9 \\
\hline $1794-$ & 15.887 & 1.718 & 10,8 & & & & \\
$1807^{*}$ & 17.000 & 1.100 & 6,5 & 12.798 & 80,0 & 1.371 & 8,6 \\
\hline $1805^{* *}$ & 17.000 &
\end{tabular}

Fuentes: elaboración de los autores a partir de Archivo General de Indias (AGI), Santa Fe, leg.43, R.4, N. 19, f.1r.; leg.1023; M. del Borrego, Palenques de negros, p. 22; AGN, SC, CVD, t.8, doc.9, fs.75r.-131r., doc.10, 132r.-164r.; AGN, SC, Miscelánea, t.44, doc.43, fs.945r.-957r.; t.41, doc.27, fs.1004r.-1079r.; AGN, Sección Mapas y Planos, Mapoteca 7, ref.:1353, f.21r; Joaquín Francisco Fidalgo, Derrotero y cartografía de la Expedición Fidalgo por el Caribe neogranadino (1792-1810), Bogotá, El Áncora Eds., 2012, p. 118. * Fidalgo estuvo en Cartagena entre 1792 y 1810. Escribió sus informes luego de retornar a España. Las cifras de población que señala no sabemos a qué año se refiere. Y solo da cifras de los esclavos más no de otros sectores socio-raciales. ** Manuel de Anguiano, "Descripción histórica de la provincia de Cartagena de Indias", en Servicio Geográfico del Ejército (España), Depósito de la Guerra, Archivo de Planos, Estante J, Tabla 5, Cartera 2a Sección a, No. 7, 1805, f.IIv.

Esos contextos divergentes a lo largo del periodo que estudiamos tuvieron sus repercusiones sobre los propietarios de esclavos. En un primer plano estaban las familias de la elite de la ciudad que poseían las mayores cantidades. Según el censo de 1777 del partido de Mahates, próximo a Cartagena, en 31 haciendas de trapiche de caña de azúcar, labranza y ganado había 954 esclavos, lo que en términos comparativos representaba el $37 \%$ del total que existía en la plaza fuerte ${ }^{28}$. Pero la documentación de pagos de alcabalas por compraventas de esclavos consultada para construir la tabla 2 muestra dos hechos que queremos resaltar. Si tomamos el reconocimiento de prestancia social expresado en el empleo de los prenominales de don/doña adscritos a la blancura, honorabilidad, y provenir y haber contraído de matrimonio católico, observamos que entre quienes realizaron compraventas existió un significativo sector integrado por blancos. Ahora bien, por el conocimiento que tenemos sobre la elite de la ciudad ${ }^{29}$, podemos inferir que en su mayoría

${ }^{28}$ AGN, SC, CVD, t.8, doc.58, fs.760v.-839v.; Hermes Tovar, Grandes empresas agrícolas y ganaderas, Bogotá, CIEC, 1980; Adolfo Meisel, "Esclavitud, mestizaje y hacienda en la provincia de Cartagena 1533-1851", en Gustavo Bell (ed.), El Caribe colombiano, Barranquilla, Universidad del Norte, 1988, pp. 69-137.

${ }^{29}$ Listados de los grandes comerciantes y hacendados que formaban la elite en: AGN, SC, CVD, t.8, doc.9, fs.75r.-131r.; doc.10, fs.132r.-164r.; AGN, SC, Miscelánea, t.44, doc.43, fs.945r.-957r.; t.41, doc.27, fs.1004r.-1079r.; AGN, SC, CVD, t.6, doc.19, fs.77r.-81v.; AGN, SC, CVD, t.6, doc.16, fs.63r.-68v.; AGN, SC, MM, t.8, doc.37, fs.703r.-709v.; AGN, SC, Aduanas, t.12, doc.17, fs.733r.-742v.; AGN, SC, Abastos, t.9, doc.11, fs.613r.-623v.; AGN, SAA I-12, fondo Empréstitos, 
aquellos blancos prestantes no formaban parte de ese sector social. Y también hubo un grueso número de transacciones en las que participaron blancos sin prestancia y pardos de condición social media y aún pobres. Era un sector que se desempeñaba en ocupaciones heterogéneas entre quienes reconocemos a mercaderes, sacerdotes, funcionarios públicos de bajo rango, militares de oficialidad media, pulperos ${ }^{30}$, escribanos, artesanos y otras personas a las que no se les señaló ocupación. La posesión de esclavos por estos sectores era asumida como una expresión de diferenciación social.

Al menos en 1803 así lo señaló una mulata libre, hija de un pintor pardo y capitán de milicias, quien, al reñirse con una blanca y esposa de un funcionario de la Real Fábrica de Aguardientes, se vanagloriaba porque pese a su condición socio-racial su familia tuvo mejor nivel de vida y algunos esclavos $^{31}$. Los esclavos constituían una fuente de ingresos económicos (alquiler, enviarlos a trabajar por un jornal, prostitución y ventas callejeras), y eran un recurso disponible que podían transar en momentos de necesidades económicas.

Tabla 2: Participación de sectores sociales en compraventas de esclavos, libros de alcabalas, 1794-1805

\begin{tabular}{|c|c|c|c|c|c|}
\hline & $\begin{array}{c}\text { Total } \\
\text { Transacciones }\end{array}$ & $\begin{array}{c}\text { Total } \\
\text { esclavos } \\
\text { transados }\end{array}$ & $\begin{array}{c}\text { Propietarios } \\
\text { con } \\
\text { prestancia } \\
\text { social } \\
\text { (don/doña) }\end{array}$ & $\begin{array}{c}\text { Propietarios } \\
\text { sin } \\
\text { prestancia } \\
\text { social }\end{array}$ & $\begin{array}{c}\% \text { de los sin } \\
\text { prestancia } \\
\text { en } \\
\text { el total de } \\
\text { transaccion } \\
\text { es } \\
\end{array}$ \\
\hline \multicolumn{6}{|c|}{ Vendieron } \\
\hline 1794 & 285 & 303 & 190 & 95 & 33,3 \\
\hline $1795^{*}$ & 185 & 204 & 123 & 62 & 33,5 \\
\hline $\begin{array}{c}1802 / 180 \\
3 \\
\end{array}$ & 171 & 178 & 119 & 52 & 30,4 \\
\hline $\begin{array}{c}1804 / 180 \\
5\end{array}$ & 294 & 328 & 223 & 71 & 24,1 \\
\hline \multicolumn{6}{|c|}{ Compraron } \\
\hline 1794 & 285 & 303 & 198 & 87 & 30,5 \\
\hline $1795^{*}$ & 185 & 204 & 137 & 51 & 27,6 \\
\hline $\begin{array}{c}1802 / 180 \\
3\end{array}$ & 171 & 178 & 113 & 58 & 33,9 \\
\hline $\begin{array}{c}1804 / 180 \\
5\end{array}$ & 294 & 328 & 246 & 48 & 16,3 \\
\hline
\end{tabular}

Fuentes: elaboración de los autores con base en: Cartagena. Libro real, común y general de aduana y alcabalas, 1794, AGN, Sección Archivos Anexos-grupo III (SAA-III), fondo 1 Aduanas, leg.6, fs.1r.-188v.; Cartagena. Libro real, común y general de aduana y alcabalas, 1795, AGN, SAA-III, 1 Aduanas, leg.7, fs.1r.-116v.; Cartagena. Receptoría. Libro común de cargo y data, 1803, AGN, SAA-III, fondo 3 Alcabalas, leg.82, fs.1r-235r.; Cartagena. Receptoría. Libro real de cargo, 1804-1805, AGN, SAA-III, 3 Alcabalas, leg.86, fs.1r.-175r. * El libro de alcabalas de este año solo comprende los meses de enero a septiembre.

leg.1, carpeta 1, fs.4r.-v.; AGN, SAA I-12, Empréstitos, leg.1, carpeta 2, fs.13r.-15r.; M. T. Ripoll, La elite en Cartagena y su tránsito a la República; S. P. Solano, M. Vanegas Beltrán y R. Flórez, "Elites y poder colonial", 44-75.

${ }^{30}$ M. Vanegas Beltrán, S. P. Solano y M. de la Cruz, "El pequeño comercio en Cartagena de Indias", 1-23.

${ }^{31}$ AGN, SC, fondo Juicios Criminales, t.215, doc.15, f.378v. 
Esta constatación nos lleva a un segundo aspecto que queremos analizar: la diversidad de propietarios implicó que los esclavos estuvieron repartidos por toda la ciudad y en sus inmediatos alrededores de extramuros. En la tabla 3 aparece la distribución de los esclavos en los cincos barrios que formaban la plaza fuerte en 1777 (ver tabla 3 y plano 1), indicando la participación porcentual entre el toda de sus habitantes, como también en el total de los de la ciudad.

Tabla 3: Distribución de los esclavos en los barrios de la ciudad, 1777

\begin{tabular}{lcccccc}
\hline & $\begin{array}{c}\text { Santa } \\
\text { Catalina* }\end{array}$ & $\begin{array}{c}\text { Santo } \\
\text { Toribio }\end{array}$ & $\begin{array}{c}\text { La } \\
\text { Merced }\end{array}$ & $\begin{array}{c}\text { San } \\
\text { Sebastián }\end{array}$ & Getsemaní & $\begin{array}{c}\text { Total } \\
\text { ciudad }\end{array}$ \\
\hline Total habitantes & 3.220 & 3.169 & 1.609 & 1.617 & 4.075 & 13.690 \\
\hline Esclavos & 813 & 682 & 488 & 339 & 202 & 2.584 \\
\hline $\begin{array}{l}\text { \% esclavos entre } \\
\text { los habitantes de } \\
\text { los barrios }\end{array}$ & 25,4 & 21,5 & 30 & 21 & 5 & \\
\hline $\begin{array}{l}\text { \% en el total de } \\
\begin{array}{l}\text { sclavos de la } \\
\text { ciudad }\end{array}\end{array}$ & 31,5 & 24,7 & 19 & 13,1 & 7,8 & $18,9 \%$ \\
\hline
\end{tabular}

Fuentes: elaboración de los autores con base en AGN, SC, CVD, t.8, doc.9, fs.75r.-131r., doc.10, 132r.-164r.; AGN, SC, Miscelánea, t.44, doc.43, fs.945r.-957r.; t.41, doc.27, fs.1004r.-1079r.; AGN, Sección Mapas y Planos, Mapoteca 7, ref.:1353, f.21r.; María Aguilera y Adolfo Meisel, Tres siglos de historia demográfica de Cartagena, Cartagena, Banco de la República, 2009, p. 22; * Cifras inferidas a partir del resumen general.

Más allá de lo que nos dice la lectura de la tabla 3 acerca de la presencia de los esclavos por toda la ciudad, y sobre la apropiación que hacían de los espacios públicos, queremos destacar un hecho a propósito de la historiografía sobre este grupo social en Cartagena. Se ha insistido en que durante el periodo colonial el arrabal de Getsemaní era el sitio de los esclavos por excelencia. Sin embargo, el censo de 1777 muestra a este barrio en un último lugar, lo que además de expresar las diferencias económicas y sociales entre los barrios, también es un indicador de los cambios que había tenido la institución de la esclavitud y la trata negrera en la ciudad.

En efecto, cuando comparamos los datos de los padrones de 1663 y 1777 se evidencia un cambio en el patrón de los sitios de concentración de los esclavos, pues según el primer padrón, en Getsemaní vivían el 22,3\% y el resto en el recinto amurallado ${ }^{32}$. Pero para 1777 en Getsemaní solo residía el 7,8\% del total de los esclavos. La cifra de 1663 muestra que durante el siglo XVII Getsemaní había sido sitio de vivienda y de depósito de esclavos recién traídos para luego venderlos ${ }^{33}$. Lo que evidencia el número de esclavos en este barrio en 1777 es que sus habitantes libres eran los que tenían menos posibilidades de ser propietarios de aquellos.

${ }^{32}$ AGI, Santa Fe, leg.43, R.4, N. 19, f.1r.

${ }^{33}$ Antonino Vidal, Cartagena de Indias y la región histórica del Caribe, 1580-1640, Sevilla, CSIC/EEHA/Universidad de Sevilla, 2002. 
Figura 1: Plano del recinto fortificado de Cartagena de Indias con los cincos barrios, ca. 1804

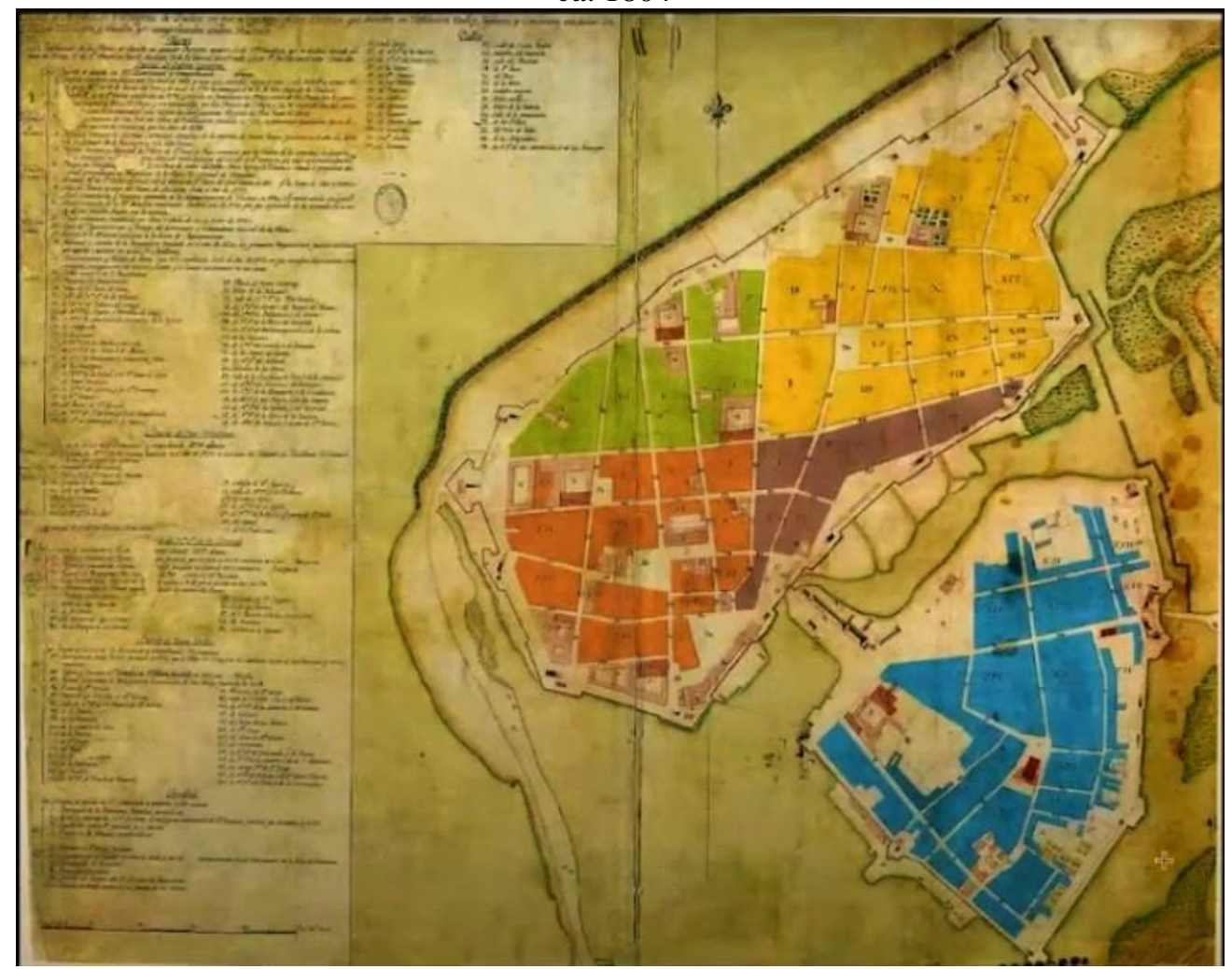

Fuente: Plaza y arrabal de Cartagena de Indias en que se representan los barrios, elaborado por Manuel de Anguiano. ca. 1804 (Cartografía y relaciones históricas de ultramar, t. 5, Madrid, Servicio Histórico Militar, 1980). Colores: verde: La Merced; amarillo: Santo Toribio; rojo: Santa Catalina; ocre: San Sebastián; azul: arrabal de Getsemaní. Nota: los cuatro barrios del recinto histórico se delimitaban en lo que hoy es la intersección de las calles en la que está situada la Universidad de Cartagena.

En contraste con Getsemaní, es significativa la presencia de esclavos en el de barrio de Santo Toribio, hecho en el que intervinieron otros factores que deben tenerse presente. Junto con los barrios de Santa Catalina, San Sebastián y La Merced, formaban parte del área del recinto fortificado sobre la que se ejercía un mejor control, si se le compara con Getsemaní. Era sitio de vivienda de los esclavos propiedad del rey cuando no estaban en los campamentos destinados a los trabajos en las fortificaciones (canteras de extracción de piedras y baterías). Los esclavos que no vivían en casa de sus amos podían alquilar habitaciones en solares y casas dado que en ese barrio eran más accesibles. Vale la pena detenerse en el padrón del barrio de Santo Toribio por dos razones: de los censos de 1777 es el que brinda mayor información sobre condiciones socio-raciales y ocupaciones, y porque tenía una composición social que resumía lo que era la sociedad de la ciudad: familias de la elite económica y política, clérigos prestantes, militares, mercaderes y pulperos, artesanos, jornaleros, esclavos, mujeres cabezas de hogar, casas altas y bajas, solares con habitaciones y áreas de servicios colectivas en los que vivían distintas familias, viviendas multifamiliares... 
Sin agotar la información del padrón de este barrio damos unos ejemplos para ilustrar la distribución de los esclavos entre personas de distintas condiciones socio-raciales y sus ocupaciones. Algunas familias tenían más de una decena de estos. En los primeros folios del padrón se evidencia una relación entre la condición social de la familia, la ubicación de las viviendas de dos plantas y el número de esclavos ${ }^{34}$. Un ejemplo es el de José de la Encarnación de Paz, mulato y hacendado, quien tenía 26 esclavos $^{35}$. Don Pedro Mas, capitán español que había sido alcalde, regidor de la ciudad y alcalde de la Santa Hermandad de la Inquisición, quien en 1777 era propietario de las tierras de Cruz Grande, al norte de las inmediaciones de la ciudad, donde tenía 9 esclavos, y 14 esclavos en su casa de dos plantas situada en la ciudad. Con 17 esclavos estaban don Rafael Escobar, regidor perpetúo y hacendado, el diezmero de la ciudad, quien poseía haciendas de trapiche en el partido de Mahates ${ }^{36}$. Una mujer blanca también poseía 17 esclavos. Con 15 un funcionario de la Real Audiencia. Con 12 un presbítero. Con 11 una mulata, el alguacil mayor de la ciudad, una mujer blanca, el Claustro de Santa Clara. Con 10 un oficial de las cajas reales, un guarda mayor de la Real Contaduría. Con 9 un hacendado blanco. Con 8 una mujer blanca, un panadero español y un abogado. Con 7 un plumario pardo, un escribano de la marina, el comisario del barrio, un blanco español y una mulata. Con 6 un mercader español, un presbítero. Con 5 un pulpero pardo, un comerciante español y un plumario blanco. Con 4 un oficial segundo de contaduría, un teniente de milicias blancas, un hortelano blanco, el ayudante menor del batallón de pardos, una mujer blanca. Con 3 un presbítero, un sastre mulato, un presbítero, un platero blanco y miliciano, una mujer cuarterona, un pardo y procurador de número, un plumario blanco, un pulpero blanco, un pulpero español y una mujer cuarterona y pulpera. Con 2 un mulato sastre y miliciano, un mercader español, un presbítero, un negro carnicero, un negro carpintero de las fortificaciones, un español pulpero, una mujer cuarterona, un español pulpero, una mujer mulata, un mulato sastre, un plumario mulato y un plumario blanco $^{37}$.

La lectura de los padrones del 1777 señala que la mayoría de los esclavos de propiedad de particulares vivía en casas de sus amos. En el del barrio de Getsemaní a la totalidad de los esclavos se les anotó como "esclavo del dicho o dicha", refiriéndose al cabeza de familia, o como de "dicha casa", es decir, que vivían con los amos (excepto un esclavo propiedad de la ciudad con su esposa y 3 hijos que vivían independiente) ${ }^{38}$. Igual registro se observa en los de San Sebastián y La Merced, y es de esperar que algo parecido acontecía en el barrio de Santa Catalina. Pero en el barrio de Santo Toribio algunos vivían de forma independiente. Aún no está del todo claro este hecho. Pero podría suponerse que lograban esa independencia a cambio de entregar a sus amos parte del jornal que ganaban desempeñando diversos oficios, como lo

\footnotetext{
${ }^{34}$ AGN, SC, Miscelánea, t.41, doc.27, fs.1004r.-1078r.

${ }^{35}$ AGN, SC, Lazaretos, t.1, doc.36, f.929v.; AGN, SC, Miscelánea, t.41, doc.27, f.1007v.

${ }^{36}$ AGN, SC, CVD, t.8, doc.58, fs.760v.-839v.

${ }^{37}$ AGN, SC, Miscelánea, t.41, doc.27, fs.1004r.-1079r.

${ }^{38}$ AGN, SC, CVD, t.8, doc.9, fs.76r.-131r.
} 
denunciaban las autoridades ordinarias y eclesiásticas y como se intentó prohibir infructuosamente desde los inicios de la ciudad ${ }^{39}$. En el padrón de este barrio, de un total de 682 esclavos, 198 (el 29\%) vivían independientes de sus amos, imaginamos que alquilando en grupos casas bajas, cuartos, solares y accesorias, o por pareja matrimonial, como también en los solares de los cabildos de negros ${ }^{40}$.

Esta condición les permitía disfrutar de cierta autonomía, mantener sus uniones maritales, y en el caso de las esclavas, y aún de algunas negras libres, escoger esposos entre los esclavos del rey, ya que esto tenían garantizado una ración diaria, asistencia médica y sobre ellos los controles quizá eran más laxos como lo demuestra la existencia de locales de sus cabildos organizados de acuerdo con las castas africanas de donde procedían. Muchos compartían habitaciones, casas bajas y solares con libres de la más baja condición social (peones, pescadores, carretilleros, vivanderos), y también compartían ciertos espacios públicos como plazas y calles. Aunque los primeros estaban por encima de los segundos debido a que eran libres, tanto por la autonomía que disfrutaban los esclavos del rey y los que tenían amos, como también por la continua lucha por el diario vivir, se aproximaban en la convivencia cotidiana.

Esa presencia en diferentes puntos del espacio urbano, interactuando con otros sectores sociales, suscitó constantes quejas y expedición de regulaciones para obligar a los propietarios a meterlos en cintura. Los bandos de buen gobierno incluían normas dirigidas a ejercer control sobre estos, y para obligar a sus amos a contenerlos para así garantizar el orden deseado por las autoridades. Desde 1553 disposiciones del Cabildo de la ciudad ordenaban que los esclavos no podían vivir por fuera de las casas de sus amos, no podían andar en los espacios públicos después del toque de la campana de queda, que los libres y los libertos no hicieran tratos comerciales con los esclavos y que no se les expendiera licores, y que tampoco se les permitiera venderlos, se prohibió reiteradamente el porte de armas, se penalizó con la muerte el ataque con arma contra cualquier blanco, se reglamentó sus reuniones festivas los domingos, castigos corporales para los esclavos que se ausentaran de las casas de los amos (azotes en el rollo público, cortes de genitales), y muerte para quienes incurrieran en cimarronaje ${ }^{41}$. Los bandos de finales del siglo XVIII volvían a ratificar parecidas normas, como muestra de que los esclavos mantenían parecidas costumbres.

Las infructuosas disposiciones expedidas en el XVIII para mantenerlos en el interior de las casas de sus amos también reflejaban viejos temores padecidos por los libres durante el siglo $\mathrm{XVII}^{42}$, cuando fueron frecuentes las posibilidades de levantamientos de esclavos. Y esto siguió operando pese a

\footnotetext{
${ }^{39}$ José P. Urueta, Documentos para la historia de Cartagena, tomo 1, Cartagena, Tip. de A. Araujo, 1887, pp.184-209, 219224.

${ }^{40}$ AGN, SC, Miscelánea, t.41, doc.2, fs.104r.-107r.

${ }^{41}$ J. P. Urueta, Documentos para la historia de Cartagena, tomo 1, pp. 184-209, 223.

42 Anthony McFarlane, "Cimarrones y palenques en Colombia siglo XVIII". Historia y Espacio, 14, 1991: 53-78;

"Autoridad y poder en Cartagena de Indias: la herencia de los Austrias", en H. Calvo y A. Meisel, Cartagena de Indias en el siglo XVIII, pp. 221-259.
} 
que durante la segunda mitad del siguiente siglo estos ya no representaban una amenaza para la estabilidad del orden de la sociedad urbana, y solo después de la revolución haitiana, renació el miedo, pero sin que llegara a ser de grandes proporciones. Pero su presencia en muchas esferas de la cotidianidad pública incomodaba a algunos sectores que pedían meterlos en cintura y penalizar a los propietarios permisivos. La información de archivo los presenta en varias dimensiones de la vida social de esta ciudad. Documentos de la segunda mitad del siglo XVIII que registraron acciones legales en los que estuvieron envueltos los esclavos, indican de situaciones que debieron causar rumores entre los esclavos de la ciudad ${ }^{43}$ : maltratos físicos propiciados por sus amos; acceso carnal con esclavas bajo la promesa de libertad; acusaciones de sodomía; participación en robos e intentos de envenenamientos, ejercitar la hierbatería; acudir a las autoridades para denunciar a los amos por maltratos, abusos sexuales e incumplimiento por parte de los herederos de voluntades testamentarias de los finados para que se les manumitiera; compras de automanumisiones o de algún familiar ${ }^{44}$. Y estos eran los pleitos judiciales que llegaban hasta Santa Fe de Bogotá, pues a nivel local en las dos alcaldías ordinarias, en la cárcel y ante los procuradores de números debieron registrarse muchas denuncias y pleitos que nunca conoceremos por la pérdida de los archivos de Cartagena. En 1771 un esclavo criollo, acudió por su propia cuenta ante uno de los alcaldes ordinarios para demandar a un mercader blanco porque le había vendido cuatro varas de un lienzo de angaripola de menor calidad que el precio pagado, lo que originó que el mercader fuese apresado hasta que satisfizo la solicitud del esclavo ${ }^{45}$. Un listado de 1792 de los procesos judiciales que se llevaban a cabo en Cartagena: causa por concubinato de esclava con hombre libre casado; esclavo enjuiciado por robo ${ }^{46}$.

La destinación de los esclavos a servir en varios frentes de trabajo no era una novedad en Cartagena de Indias del XVIII, como lo han puesto de presente estudios sobre el siglo XVII ${ }^{47}$. Un grueso número de esclavos se desempeñaban en diversas labores domésticas como el aseo, lavado de ropas, mantenimiento del buen estado de la casa, mandados, crianza de los/as niños/as blancos y demás. Sin embargo, los amos encontraron diversas formas

\footnotetext{
${ }^{43}$ AGN, SC, Negros y Esclavos-Bolívar, t.1, fs.1-128; t.5, fs.1-144; t.13, fs.1-156; t.10, fs.1-118; t.7, fs.1-44; t.1, fs.1-20; t.5, fs.1-172; t.11, fs.1-334; AGN, SC, Curas y Obispos, t.8-bis, doc.8, fs.116r.-v.; AGN, SC, Juicios Criminales, t.217, doc. 4 , fs. $495 \mathrm{r} .-501 \mathrm{v}$.

${ }^{44}$ Luz A. Maya, "Paula de Eguiluz y el arte del bien querer. Apuntes para el estudio del cimarronaje femenino en el Caribe, siglo XVII". Historia Crítica, 24, 2002: 101-118; Roland Anrup y Angélica Pérez, "De la hostia a la horca: el delito de un mulato en Cartagena de Indias del siglo XVIII". Anales, 1, 1998: 55-90; Carolina Giraldo, "Esclavos sodomitas en Cartagena colonial. Hablando del pecado nefando". Historia Crítica, 20, 2001: 171-178; L. Giolitto, "Esclavitud y libertad en Cartagena de Indias", 63-91; D. Romero, Los afroatlanticenses, pp. 97-120; F. Rangel, Entre la libertad y la esclavitud; S. Taborda, La esclavitud en Cartagena en la segunda mitad del siglo XVIII; D. Hernández, Esclavos y esclavas en el acceso a la libertad en Cartagena y Mompox; D. Sánchez, La esclavitud y sus conceptos en Cartagena de Indias; F. Avendaño, Vías legales usadas por los esclavos en la colonia.

45 AGN, SC, MM, t.12, doc.86, fs.487r.-495v.

${ }^{46}$ AGN, SC, Juicios Criminales, t.217, doc.16, fs.595r.-608v.

${ }^{47}$ A. Vidal, Cartagena de Indias y la región histórica del Caribe, pp. 263-274; M. Navarrete, Génesis y desarrollo de la esclavitud en Colombia; Julián Ruiz Rivera, "Gobierno, comercio y sociedad en Cartagena de Indias en el siglo XVII", en Haroldo Calvo y Adolfo Meisel (eds.), Cartagena de Indias en el siglo XVII, Cartagena, Banco de la República, 2007, pp. 353-376; Margarita Garrido, "Vida cotidiana en Cartagena de Indias en el siglo XVII", en H. Calvo y A. Meisel, Cartagena de Indias en el siglo XVII, pp. 451-498.
} 
para que los esclavos fueran productivos. En 1748 Jorge Juan y Antonio de Ulloa escribían que los negros,

... se dividen en dos estados, que son libres y esclavos, y uno y otro en otros dos, que son criollos y bozales; una parte de estos últimos está empleada en el cultivo de las haciendas, y estancias. Los que habitan en la ciudad, se ejercitan en los trabajos recios, con que ganan su jornal y de él dan a sus amos un tanto diariamente, se mantienen de lo que les queda... Lo mismo sucede con las negras esclavas, de las cuales unas se mantienen en las estancias casadas con los negros de ellas, y otras en la ciudad ganando jornal, y para ello venden en las plazas todo lo comestible, y por las calles las frutas, y dulces del país de todas especies, y diversos guisados, y comidas, el bollo de maíz, y el casabe que sirven de pan, con que se mantienen los negros ${ }^{48}$.

Y pocos años después, en 1752, el obispo de la ciudad se quejaba ante las autoridades de Madrid porque,

... otras familias mantienen un número excesivo, no para ocuparlos en las casas, sino para enviarlos fuera, a ganar el jornal, y aunque una porción de estos, forma con utilidad del comercio, las cuadrillas que se ocupan de las cargas y descargas de los navíos, hay otros a quienes sus dueños reparten por la ciudad a distintos trabajos, y si el pobre esclavo no lleva a la noche el jornal acostumbrado, es azotado cruelmente. Que siendo esto tan malo es muy tolerable respecto a lo que pasa con las pobres esclavas (cuyo número es casi duplicado de el de los esclavos), porque algunas familias tienen catorce, 16 y aún 17 para que vayan a ganar el jornal, vendiendo tabacos, dulces y otras cosas, de que se sigue que si la esclava no es de conciencia escrupulosa (cosa rara en esta gente), o no puede vender lo que le da su ama, es preciso procure, si no quiere ser castigada cruelmente, sacar por medios ilícitos el jornal, habiendo amas de conciencia tan depravada, que si la negra no pare todos los años la venden por inútil. Que otras usan para aplicarlas a servir en diferentes casas particulares que las necesitan, sin el menor cuidado de las operaciones de la esclava, como si de ellas no hubiera de dar estrecha cuenta a Dios, y no falta alguna tan desalmada, que en dándole la esclava un tanto cada mes, le permite vivir a su libertad en casa aparte, siendo tropiezo de la juventud, la que nunca dice, hubiera creído, si como juez no le constara ${ }^{49}$.

El dominio de un oficio servía a los intereses del propietario al poder aumentar los valores de sus esclavos en posibles transacciones comerciales, y a aquellos les permitía ciertos márgenes de autonomías (vivir por fuera de la casa del amo, lograr permanecer al lado de su pareja e hijos/as) y alcanzar algunas ganancias que les permitieran automanumitirse ${ }^{50}$. Los inventarios de los tejares expropiados a la Compañía de Jesús permiten conocer que tenían sus especializaciones laborales ${ }^{51}$. Una relación de 1794 del tejar del Tejadillo,

\footnotetext{
48 Jorge Juan y Antonio de Ulloa, Relación histórica de un viaje a la América Meridional, parte primera, tomo primero, Madrid, Imp. de Antonio Marín 1748, p. 43.

${ }^{49}$ Archivo Histórico Nacional de Madrid, Códices, t.689, Cedulario de Indias, vol. VI, f.143r.; "Diccionario de gobierno y legislación de Indias. N.", en Archivo Histórico Nacional de Madrid, Códices, t.742, exp. 82.

${ }_{50}$ Maribel Arrelucea, Replanteando la esclavitud. Estudios de etnicidad y género en Lima borbónica, Lima, Centro de Desarrollo Étnico/Centro Cultural España, 2009.

${ }^{51}$ AGN, SC, Temporalidades, t.3, doc.12, fs.605r.-610v.
} 
ya en manos del obispo de Cartagena, indica que se especializaban en distintos oficios y que en sus valores la experticia laboral desempeñaba una función central. En ese tejar había un total de 45 esclavos. De esa cifra uno era el carpintero y maestro de tejas; un herrero; un maestro ladrillero; un maestro ladrillero y tejero; un maestro ladrillero y tejero, albañil inteligente de todo lo anexo al tejar; un oficial de ladrillos y tejas; 8 oficiales de ladrillos y tejas, carga y quemar hornos y todos los anexos a la oficina del tejar. Y el propietario de este tejar, el obispo Jerónimo Liñán en su casa tenía para su servicio a un cocinero y cochero, 2 volanteros, una cocinera y lavandera y a un maestro sastre. Si a la juventud se unía el dominio de un oficio el precio aumentaba. Por ejemplo, los 8 oficiales de ladrillos y tejas, carga y quemar hornos y todos los anexos a la oficina del tejar, eran menores de 25 años y cada uno fue avaluado en 400 pesos. El maestro ladrillero y tejero, albañil inteligente de todo lo anexo al tejar tenía 54 años y fue avaluado en 340 pesos. Estos valores estaban por encima del establecido al carpintero y maestro del tejar, de 60 años, y avaluado en 280 pesos $^{52}$.

Otros podían especializarse en uno o más oficios. En1762 el esclavo Fernando Morillo ("el negrito"), quien llevaba más de diez años como propiedad del coronel de infantería del batallón Fijo homónimo que llegó a ocupar la gobernación de la ciudad y su provincia, y para quien se desempeñaba como volantero, escribió, con su puño y letra, sendas cartas al virrey Pedro Messía de la Cerda informándole los maltratos a que era sometido por su amo y solicitándole que, haciendo valer su jerarquía, lo comprara por la suma de 350 pesos, sugiriéndole que el pago lo hiciera por medio de uno de los oficiales de las reales cajas de la ciudad. El esclavo conoció al virrey en Cartagena cuando fue puesto a disposición del virrey conduciendo el carruaje en que se desplazaba. Entre las diversas razones para suplicar su compra, hay algunas que permiten conocer cómo era su vida. Una señala que estaba sometido a tantas presiones que le imposibilitaban

[...] no ser árbitro para adquirir un real, esto es, sin faltar en nada a su amo, en la habilidad de peluquero en lo que le impide se ejercite con lucro alguno, no dándole hueco [sic!] para salir de casa jamás si no es a diligencia de su servicio, de cuyo beneficio gozan todos los esclavos. Estando por ello, y por no darle el sustento necesario, próximo el suplicante a cometer cualquier yerro, para reparo de sus hambres. Lo que sucede es que va donde el pulpero a pedirle fiado ya el real, ya los dos reales, cargándose por ello de deudas, de que inferir se debe que llegará a contraer alguna crecida, y que no teniendo de donde pagar por no poder adquirirlo con su habilidad, se verá precisado a buscarlo prestado, y tal vez, si no lo encuentra, a hurtarlo, que todo cabe en la fragilidad de los hombres, y más en aquellos que por ser desdichados, no encuentran otros medios de que valerse $[\ldots]^{53}$.

\footnotetext{
${ }^{52}$ AGN, SC, Curas y Obispos, t.3, doc.10, fs.922v.-923v., 932v.-934v.

${ }^{53}$ AGN, SC, MM, t.64, doc.32, fs.261r.-266v. Cursivas nuestras.
} 
Antes de que la corona promulgara las leyes que reglamentaron el gobierno y control de los esclavos (1789), estos habían logrado algunos reconocimientos por parte de las autoridades encargadas de regular los tratos que les daban sus amos. El bando de $1784^{54}$ contenía normas que cinco años después aparecen de forma literal en el bando de $1789^{55}$, el que introdujo las regulaciones de lo que se ha denominado en código negro expedido en este último año ${ }^{56}$. Esas normas locales y para todo el imperio exigían que los amos enseñaran la doctrina cristiana, que les dieran techo y vestido, que sus matrimonios no fuesen disueltos mediante ventas que implicaran el traslado de uno de los cónyuges a otra población, que los protegieran en la invalidez de la vejez, que los días festivos no los obligaran a realizar trabajos pesados y evitar el maltrato físico. También prohibían que se les utilizara en las boticas por temor a que accedieran a drogas que envenenaban; que tenderos y mercaderes no les fiaran artículos; que no se les socorriera por personas libres cuando huían de casa de sus amos; no se permitía que se enviara a las esclavas de corta edad a ganar jornal y a vender granjerías por las calles.

\section{Los esclavos del rey}

Los esclavos de propiedad de la corona era el otro contingente que hizo presencia en Cartagena. En amplia mayoría eran esclavos bozales, y se les destinaba a los trabajos de reparaciones y construcciones de las fortificaciones y de las canteras de piedra y los hornos de cal anexos situadas en los inmediatos alrededores de la ciudad y en la isla de Tierra Bomba. Compras, donaciones de particulares y esclavos de estos condenados a trabajos por delitos graves, formaron parte de la fuerza de trabajo en esos sistemas defensivos.

En los listados semanales elaborados por los sobrestantes de las obras de fortificaciones con el fin del reconocimiento de raciones, estos esclavos aparecen con apellidos tomados de las castas de las que provenían (Arará, Carabalí, Cofi, Congo, Chalá, Malungo, Mandinga, Masuanga, Mina, Yanta, Queque, Algine, Icasala, Coacu, Adane, Parenana, Coami, Ocura, Yara, Yata, Sago, Acuamera, Maní, Obuichi, Osso, Vacara, Obacile, Acuana, Ago, Sungu, Sungulo, Bihimi, Bahan, Sunsi, Mucy, Ciba, Muanza, Panzo, Lenda, Bangu, Miala, Moanda, Mauín, Emfica, Panlo, Incomle, Binda, Mauinga, Obancu, Vira, Coyo, Macoso, Empuco, Petelo, Enguete, Soloca, Banzu, Emfula, Bris, Cunilí, Bariguale, Oru, entre otros ${ }^{57}$. Los ingenieros tenían preferías por esclavos de determinadas castas al considerar que tenían mejor disposición para el aprendizaje de los oficios. En 1755 Antonio de Arévalo se quejaba porque de los 100 esclavos bozales pocos eran congos y carabalíes (a

\footnotetext{
${ }^{54}$ AGN, SC, MM, t.130, doc.61, fs.228r.-258r.

55 "El deber de vivir ordenadamente y de obedecer al rey". Anuario Colombiano de Historia Social y de la Cultura, 20, 1992: 109-131.

${ }^{56}$ Manuel Lucena Salmoral, Leyes para esclavos. El ordenamiento jurídico sobre la condición, tratamiento, defensa y represión de los esclavos en las colonias de la América española, Madrid, Fundación Larramendi, 2000; María E. Chaves, "Paternalismo, iluminismo y libertad. La vigencia de la Instrucción esclavista de 1789 y su impacto en la sociedad colonial". Historia y Sociedad, 11, 2011: 69-93.

${ }^{57}$ AGN, SAA-I, fondo Guerra y Marina (GM), caja 6, carpeta 2, fs.30r.-v.; caja 24, carpeta 8, fs. 160r.-v.; Rogelio Velásquez, "Gentilicios africanos del occidente de Colombia". Revista Colombiana de Folclor, II, (7), 1962: 107-148.
} 
los que consideraba mejores trabajadores), mientras que en su mayoría eran araraes, chochos y chalá ${ }^{58}$.

A estos esclavos se les criollizaba, se les preparaba en ciertas labores, en especial en el trabajo de canteras, y luego, de acuerdo con las necesidades de otras plazas fuertes, como Portobelo y Panamá, por ejemplo, se les enviaba a trabajar en esas fortificaciones. Y también se optaba por venderlos. Era un contingente móvil, de acuerdo con las necesidades defensivas del imperio en Hispanoamérica. Cuando se adquirieron en 1753 los 100 con destino a Portobelo, se hizo con la condición de venderlos cuando culminaran los trabajos, condición que retomó el gobernador de Cartagena en 1760 dadas las urgencias pecuniarias de las obras ${ }^{59}$.

Las compras las solicitaban los ingenieros militares que estaban al frente de los trabajos y debían tener autorización de la corona. En las canteras eran barreteros (empleaban las barras para desprender los bloques de piedra de las canteras), extraían las piedras y las cargaban en las carretas tiradas por bueyes para ser llevadas a los botes que luego las transportaban a los sitios de trabajo en las fortificaciones. También atendían los hornos en los que se colocaban las piedras para producir la cal que luego se empleaba en la elaboración de la argamasa de las construcciones. Otros, en otra labor también especializada, eran canteros-talladores que daban forma a las piedras. Además, cuando la corona monopolizó la producción y comercialización del aguardiente, en la Real Fábrica de este producto también trabajaban esclavos del rey. En 1787 se compraron 20 con el fin de que trabajaran atendiendo el fuego de los fogones de los alambiques de la fábrica de Cartagena, cantidad que se mantenía en 1794 a los que se le reconocía 2 reales diarios ${ }^{60}$. Pero para 1807 solo quedaban 8 , y el administrador señalaba que el trabajo en medio de un calor insoportable los enfermaba y hacía mella en sus estados físicos. Consideraba que la dureza del trabajo no permitía que se les reemplazara por trabajadores libres pues estos trabajaban de mala fe y la máxima pena era despedirlo, mientras que a los esclavos se les castigaba y eso era un acicate para que mejoraran en el desempeño de sus labores ${ }^{61}$.

La tabla 4 contiene cifras sobre el empleo de esclavos del rey en los trabajos de fortificaciones. La información empieza en 1722, cuando el sobrestante señaló que había en la ciudad 70 esclavos del rey. Años después, cuando empezaron en firme los trabajos de reconstruir y construir buena parte de las fortificaciones, el problema de la escasez de mano de obra se hizo evidente. En 1749, por petición de los ingenieros directores de las obras de fortificaciones, se compraron $50^{62}$. Para mediados de ese siglo la cifra

\footnotetext{
${ }^{58}$ AGN, SC, Negros y Esclavos-Panamá, vol. IV, t.4, f.902v.; Archivo General de Simancas-España, Secretaría de Estado y Despacho de Guerra (AGS, SEDG), leg.7236, exp.9, fs.66r.-69r.; María del C. Borrego, Cartagena de Indias. La andadura de una vida bajo la colonia, Bogotá, El Áncora Eds., 2010, pp. 101-102.

${ }^{59}$ AGN, SC, MM, t.87, doc.81, fs.428v.-429r.

${ }^{60}$ Joaquín Durán y Díaz, Estado general de todo el virreinato de Santafe de Bogotá, Bogotá, Banco de la República 1794, pp. 183-184.

${ }^{61}$ AGN, SC, fondo Negros y Esclavos-Bolívar, t.5, doc.2, f.258r.-42v.

${ }^{62}$ AGN, SAA-I, GM, caja 6, carpeta 2, f.82v.
} 
aumentó por compras solicitadas por el ingeniero Antonio de Arévalo para los trabajos en las canteras ${ }^{63}$. En 1759 se alcanzó la cifra más alta del periodo, manteniéndose durante el siguiente decenio para luego empezar a caer hasta casi desaparecer a finales del XVIII.

Tabla 4: Empleo de esclavos del rey en obras de fortificaciones, 1722-1802

\begin{tabular}{llcc}
\hline Años & \multicolumn{1}{c}{ Cantidades } & Años & Cantidades \\
\hline 1722 & 70 & 1771 & 175 \\
\hline 1741 & 142 & 1776 & 140 \\
\hline 1751 & 139 & $1782-1783$ & 182 \\
\hline 1753 & 164 & 1788 & 78 \\
\hline 1756 & 232 & 1792 & 67 \\
\hline 1759 & 235 & 1793 & 66 \\
\hline 1760 & 228 & $1796-1797$ & 50 \\
\hline 1770 & 111 & $1801-1802$ & 7 \\
\hline
\end{tabular}

Fuentes: elaboración de los autores a partir de: AGN, SAA-I, GM, caja 6, carpeta 2, f.82v.; caja 7, carpeta 17, fs.422r.-423v.; caja 2, carpeta 20, fs.794r.-796v.; caja 6, carpeta 2, fs.26r., $28 \mathrm{r} .-29 \mathrm{v}$.; caja 24 , carpeta 8 , fs.155r.-159r., $167 \mathrm{r}$.-169v., $185 \mathrm{r}$--v.; caja 59, carpeta 1 , fs.1r.5v., 11r.-12r., 17r.-18r., 23r. y v., 29r.-30r., fs.42r.-110r.; AGN, SC, Miscelánea, t.116, doc.73, fs.503r.-v.; t.120, doc.6, f.26r.; AGN, SC, fondo Archivos, t.3, doc.27, f.738v.; AGN, SC, MM, t.87, doc.81, fs.429r.; t.8, doc.35, f.615r.; t.37, doc.5, f.132r.; t.16, doc.189, f.1032v.; AGS, SEDG, leg.7236, exp.9; leg.7240, exp.31; J. Marchena, La institución militar de Cartagena de Indias 1700-1810, pp. 307, 317; AGN, SC, fondo Mejoras Materiales, t.21, doc.19, fs.494r.-516r.

Estos esclavos realizaban los trabajos más difíciles y riesgosos en las fortificaciones. En 1756 parte del lote de los 232 esclavos del rey se utilizaba en la construcción de estacadas y colocación de piedras que debían contener el oleaje marino para facilitar la construcción del fuerte de San Fernando de Bocachica. Esto significaba trabajar metidos en el agua y en la marisma, con técnicas precarias que hacían muy difícil las labores. Sumergidos en el agua colocaban cajones de mampostería, piedras y estacadas que constituían los cimientos de las obras o para detener y alejar el oleaje del mar. También trabajaron en la construcción de la escollera submarina de Bocagrande con la que se cerró el paso de los barcos hacia la bahía interior de la ciudad. En 1782 había 126 esclavos del rey laborando en esas obras ${ }^{64}$. Se les reconocía diariamente unas limetas de aguardiente.

Sus labores eran dirigidas por los sobrestantes y por artesanos peritos en los oficios. En 1721 el virrey de la Nueva Granada ordenaba que se iniciaran los trabajos de las fortificaciones que daban hacia el Mar del Norte (mar Caribe) solo empleando a un maestro albañil, cuatro oficiales, cuatro canteros y 80 esclavos del rey ${ }^{65}$. En 1751 una tercera parte de los 139 esclavos del rey adscritos destinados a las fortificaciones, que trabajaban en la reconstrucción

\footnotetext{
${ }^{63}$ AGN, SC, Miscelánea, t.116, doc.73, fs.503r.-v.; AGN, SC, Negros y Esclavos-Panamá, vol. IV, t.4, fs.899r.-906v.; Archivo Histórico Nacional de Madrid, Codices, t.699, Cedulario de Indias, vol. XVI, f.237v. AGN, SC, fondo Archivos, t.3, doc.27, f.738v.

${ }^{64}$ AGN, SAA-I, GM, caja 24, carpeta 8, fs.185r.-v.

${ }^{65}$ AGI, Santa Fe, leg. 472.
} 
de la batería de San José de Bocachica y el acondicionamiento del Castillo Grande de Bocagrande para depósito de pólvora, desempeñaban oficios de albañiles, canteros, barreteros, mandador cofi mina (especie de capataces al frente de sus congéneres, en especial cuando eran esclavos bozales que aún no hablaban la lengua castellana), carpintero, arraes de canoas ${ }^{66}$. Hubo un contingente de estos que alcanzó el dominio de algunos oficios y se convirtieron en hábiles artesanos, en especial en los oficios ligados a la construcción, los que, aparte de la ración diaria de real y medio, se les reconocía "una gratificación" por los días que trabajaban ${ }^{67}$. El monto de esta gratificación dependía del oficio al que se les destinara. Los albañiles, canteros, mandador cofi, carpinteros, arraes se les reconocía medio real. A los segundos arraes un cuartillo. A los negros de barra (barreteros) lo siguiente: a los mandadores barreteros medio real; a los barreteros un cuartillo.

Las autoridades corrían con los gastos de manutención, vivienda y vestido, y el sepelio, para lo que se tenía destinada la suma de diez pesos ${ }^{68}$. La ración diaria equivalente a real y medio se mantuvo estable durante los años transcurridos entre 1741 y 1805 . Según las ordenanzas militares ese era el valor de una ración de alimentos que equivalía a 34 onzas $^{69}$. En la información de archivos rastreada desde 1732 real y medio fue considerado el rasero mínimo de la dieta diaria de una persona adulta y era el valor de la ración que se daba a los esclavos del rey para su manutención ${ }^{70}$. Igual cantidad se destinaba para el pago de sus convalecencias en el Hospital de San Juan de Dios. En 1795 varios esclavos de un particular recibían igual cantidad de dinero $^{71}$. Lo que se podía consumir con ese real y medio variaba debido a las modificaciones sufridas en los precios de los artículos de primera necesidad a lo largo de los años que estudiamos, Un reciente estudio muestra que desde el decenio de 1780 empezaron a subir los precios de los artículos de primera necesidad, lo que indica que los esclavos de la corona padecieron mayores afecciones en su precario nivel de vida ${ }^{72}$. Un informe rendido en 1809 por el ingeniero de la plaza sobre las raciones de los presos forzados (también real y medio), plenamente válida para los esclavos de la corona, se refiere a la relación costo de vida y la capacidad adquisitiva de esa corta suma

[...] en la actualidad se mantienen los presidarios con la misma ración de real y medio diarios que fue señalada en aquellos primitivos tiempos en que se estableció el presidio, y cuya fecha ignoro, pero que considerada solo desde mediados del siglo pasado que trabajaban ya en los castillos de Bocachica, se sabe por notoriedad en Reales Obras que apenas alcanzaba para la precisa manutención por escasa que fuera. Por consecuencia en el

\footnotetext{
${ }^{66}$ AGN, SAA-I, GM, caja 6, carpeta 2, f.26v.

${ }^{67}$ AGN, SAA-I, GM, caja 6, carpeta 2, f.26r.

${ }^{68}$ AGN, SAA-I, GM, caja 7, carpeta 17, f.488r.

${ }^{69}$ AGN, SC, MM, t.38, doc.8, fs.270r.-v.; AGN, SAA-I, GM, caja 6, carpeta 2, ff.30r.; caja 24, carpeta 8, fs.160r.-v., 172r.v., 185r.-v.; caja 59, carpeta 1, f.5r., 7r.-v., 13r.-v., 19r.-v., 25r.-v., 31r.-v., 81r.-v., 87r.-v., 93r.-v., 99r.-v., 112r.-v; 118r.-v.,, 124r.-v., 130r.-v., 136r.-v., 146r.-v., 153r.-v., 159r.-v., 165r.-v., caja 90, carpeta 2, fs.386r.-391r.; AGN, SAA I-17, fondo Historia, t.3, doc.9, fs.36r.-37r.; AGN, SC, Miscelánea, t.120, doc.6, f.26r.; AGN, SC, MM, t.8, doc.35, f.615r.

${ }^{70}$ AGN, SC, fondo Real Audiencia, Bolívar-Venezuela, t.1, doc.3, fs.196r.-197v.; AGN, SAA-I, fondo Historia, t.3, doc.9, fs. $36 \mathrm{r} .-37 \mathrm{r}$.

${ }^{71}$ AGN, SC, CVD, t.1, doc.3, f.818r.

72 S. P. Solano, "Trabajadores, jornales, carestía y crisis política en Cartagena de Indias", 549-588.
} 
día que han aumentado los víveres considerablemente es imposible darles dos ranchos calientes, como lo exige la naturaleza de los trabajos a que son destinados. De modo que reducidos a una sola comida al mediodía, bastante escasa y falta de sustancia, con el real que cada individuo mete en rancho, se les entrega el medio restante por vía de sobras, con cuyo cortísimo auxilio han de almorzar o cenar, han de vestir y fumar, que son los menos gastos que se les puede considerar, aun suponiendo que ellos mismos se laven la ropa, y se afeiten alguna vez ${ }^{73}$.

Por una consulta que hicieron en 1768 las autoridades de Santa Fe de Bogotá a los oficiales de las cajas reales de Cartagena, sobre lo que debían pagar a unos esclavos del rey que de esta ciudad se enviaron a aquella para que trabajaran en las labores de construcción de la real fábrica de pólvora, en especial en la confección de sus hornos, sabemos que, además del mencionado jornal, también se les daba dos vestidos ("camisa regular y calzón largo") de gantes al año, en caso de enfermedad se les atendía en el Hospital San Juan de Dios con la misma asignación del real y medio. Para los sepelios tenían su caja, pagando al mes un real, teniendo que reunir durante su vida productiva 18 pesos que era el valor de los oficios religiosos y de la sepultura. Luego agregaban: “... cada uno tiene de gratificación aquello que merece según su oficio y habilidad...", es decir un reconocimiento monetario además del jornal, indicando que a los canteros, albañiles y herreros sobresalientes se les reconocía un real, y en su orden, se les daba medio real a carpinteros, ladrilleros y horneros. En 1732 los esclavos del rey lograron un acuerdo para que no se les diera sepelio de cementerio en las afueras de la ciudad, sino de iglesia. Y para ello acordaron un monto de diez pesos que iban reuniendo mediante descuentos de sus raciones ${ }^{74}$.

Estos esclavos debieron estar relacionados con los cabildos de carabalíes, chalaes, lucumíes, jojoes, araraes, luangos, que aparecen registrados en el censo de 1777 del barrio de Santo Toribio ${ }^{75}$. Y estos esclavos, organizados en cabildos por castas podían tener sus espacios como sucedió en 1794 cuando el "... mayoral de los negros carabalíes, por si y los de su casta" compraron por 150 pesos el solar donde funcionaba su cabildo, en la calle de San Pedro Mártir, barrio de Santo Toribio"76. La documentación consultada permite conocer que cuando trabajaban en las afueras de la ciudad (canteras y fortificaciones) vivían en campamento construidos con ese fin. Que en canteras y obras laboraban bajo la vigilancia de sargentos, cabos y capataces. $\mathrm{Y}$ de noche se les encadenaban a un tambor para evitar huidas. Cuando venían a la ciudad por razones de enfermedad o accidentes en el trabajo o cuando laboraban en esta, se les alojaba en una casa arrendaba con dineros reales, bajo la vigilancia de un mayordomo y de dos sobrestantes. Las relaciones mensuales de pagos de ese año indican que hasta el mes de noviembre de 1751 se incluyó en el presupuesto de las fortificaciones el pago del arriendo

\footnotetext{
${ }^{73}$ AGN, SC, Abastos, t.10, doc.7, fs.124v.-125r.

74 AGN, SAA-I, Historia, t.3, doc.9, fs.36r.-v. AGN, SAA-I, GM, caja 11, carpeta 17, fs.446r.-501v.; AGN, SC, Real

Audiencia, Bolívar-Venezuela, t.1, doc.3, fs.190r.-199r.

75 AGN, SC, Miscelánea, t.41, doc.27, fs.1004r.-1079r.

${ }^{76}$ AGN, SAA-III, 1 Aduanas, leg.6, Cartagena. Libro real, común y general de aduana, 1794, f.154v.
} 
de la casa cuartel ${ }^{77}$. La decisión de suprimir ese rubro se debió a que, desde el decenio de 1750 en adelante, con la intensificación de los trabajos en los fuertes de San Fernando y San José, en Bocachica, a la entrada de la bahía, a los esclavos reales los alojaron en los campamentos que se levantaban con tablas y techos de pajas en las áreas donde se realizaban las obras ${ }^{78}$. Y a comienzos de los años de 1770 para adelantar las labores de construcción de la escollera submarina de Bocagrande se levantó un campamento para albergar a los trabajadores, esclavos del rey y a los desterrados condenados a trabajo forzado, como también para depósitos de las herramientas y máquinas que se empleaban y talleres de herrería para refaccionarlas, carpintería y calafatería. Sin embargo, continuó subsistiendo el problema de qué hacer con los esclavos inválidos y con los enfermos que eran tratados en el Hospital San Juan de Dios de Cartagena. Pues bien, es posible que estos esclavos sean los que vivían en Santo Toribio, en las casas de los cabildos. Este barrio estaba situado en el recinto fortificado y por tanto era de más fácil control por parte de las autoridades. Además, era donde más se arrendaban habitaciones.

\section{El declive de la esclavitud}

La tabla 1 muestra que entre 1663 y 1751 decreció la proporción de los esclavos en el total de habitantes de la ciudad, para luego tener una recuperación en 1777, y para volver a caer más tarde, en 1805. Algo parecido sucedió con el contingente de esclavos de la corona (tabla 4). Las razones fueron diversas. En los inicios del siglo XVIII la trata de esclavos venía siendo gestionada con asentistas privados y grandes compañías inglesas, holandesas y francesas. Sin embargo, hubo dificultades en la obtención de esclavos y tensiones entre los funcionarios españoles dada la intromisión extranjera en el negocio. Hacia la segunda mitad del siglo, la amenaza extranjera fue más latente y Cartagena vio acentuada su crisis en el comercio de esclavos. Más aún, la ruptura con el sistema de monopolios que implementó España la ubicaron en un lugar secundario. La liberalización del comercio en 1778, era una estrategia que respondía a facilitar la introducción masiva de esclavos para satisfacer las necesidades de las grandes plantaciones americanas $^{79}$. Al ser parte de la política de reformas borbónicas, dicha liberalización se sumó a la reorientación de la ciudad de principal puerto esclavista a centro defensivo de la metrópolis. Hacia finales del siglo, la política reformista en torno a la esclavitud estableció en 1789 la libertad en la trata de esclavos, sin embargo, para la Nueva Granada sólo se extendió en 1791. Tras la clausura con los grandes asientos internacionales, los reyes españoles recurrieron a pequeños asientos para surtir sus colonias ultramarinas, hasta que Carlos III acentuó finalmente las políticas de reformas. El 16 de octubre de 1765 otorgó la libertad de comercio a las grandes Antillas y a Caracas para negociar con nueve puertos de España. De esa forma, los esclavos del rey antes llevados al área continental del Caribe,

\footnotetext{
${ }^{77}$ AGN, SAA-I, GM, caja 6, carpeta 2, fs.26v., 82r.-83v.; AGN, SC, Miscelánea, t.74, doc.47, fs.467r.-v.

${ }^{78}$ AGN, SAA-I, GM, caja 6, carpeta 2, f.32r.

${ }^{79}$ J. Palacios, La trata de negros por Cartagena de Indias, p. 174.
} 
fueron redireccionados hacia el área insular. La real cédula de 1791 prorrogó la libertad de trata por seis años y con el mismo carácter experimental de la vez anterior, exigiéndose por ello que las autoridades de los puertos habilitados informaran del número de negros introducidos. Los puertos habilitados para recibir los esclavos fueron los siguientes: Cartagena en la Nueva Granada; Montevideo en el de Buenos Aires; Caracas, Puerto Cabello, Guaira, Maracaibo, Cumaná y Nueva Barcelona en la Capitanía General de Venezuela; Santo Domingo; San Juan en Puerto Rico; y La Habana en $\mathrm{Cuba}^{80}$. Antes de la libertad de la trata la importación de esclavos por el puerto de Cartagena estuvo restringida, hecho que, junto al fracaso de España en la política de la trata, explica la disminución de los esclavos del rey en la ciudad. En ese contexto, la población esclava de Cartagena había disminuido tal como lo consignamos en la tabla 1 .

Otras circunstancias también explican la disminución de la cantidad de esclavos en la ciudad. Sometidos a continuas compraventas y a cambios de amos, hasta podían ser sacado de la ciudad y enviado a trabajar en las haciendas. Esto implicaba un desarraigo espacial que desestructuraba el tejido de sus relaciones familiares y sociales construido. Uno de tantos ejemplos es el siguiente: En 1797 un esclavo, acusado por dos robos fue condenado a azote y a destierro, pero su propietario, avecindado en la parroquia de Remolino en jurisdicción de la provincia de Santa Marta, para evitar tener que venir a Cartagena, hizo graciosa donación del esclavo al rey. Y para eso se reconstruyó la tradición de propiedad. En 1782 siendo propiedad de una morena libre, quien lo había comprado a la marquesa de Valde Hoyos, lo vendió a doña Inés de Hoyos. En ese año esta lo vendió a don Antonio Gutiérrez de la Torre, y éste, 2 años después, lo vendió a Francisco Gravete, quien, a su vez, en 1788, lo transfirió a Antonio de Arévalo. Inmediatamente este ingeniero lo cambió a un hacendado de la parroquia de Sabanagrande, por un esclavo bozal. Y este lo traspasó al propietario que lo donó al rey. En un lapso de 15 años pasó por ocho propietarios y salió de Cartagena ${ }^{81}$.

De acuerdo con los ciclos de la economía local y provincial, operó la circulación de los esclavos entre el espacio urbano y el rural. Por ejemplo, a comienzos del siglo XIX cuando miembros de la elite constataron que el abasto de la ciudad podía ser un negocio rentable y compraron tierras entre el pie de monte de los Montes de María y la costa del mar Caribe para levantar ganado y sembrar caña y productos alimenticios, también compraron esclavos en la ciudad y los mandaron a trabajar a sus haciendas. En 1795 el ingeniero Antonio de Arévalo, propietario de la hacienda de San Antonio de Cocó compró 6 esclavos $^{82}$. Entre 1804-1805 Santiago González (hacendado, comerciante, asentista de víveres al apostadero de la marina) compró 20, Juan de Dios Amador 19, Antonio José de Ayos, Hilario de la Espriella, Juan del

\footnotetext{
${ }^{80}$ M. Lucena Salmoral, Leyes para esclavos, pp. 153, 269, 343.

${ }^{81}$ AGN, SC, Negros Esclavos-Bolívar, t.3, doc.8, fs.1081v.-1087r.

${ }^{82}$ Cartagena. Libro de conciertos y obligaciones con mercaderes, pulperos y hacendados, 1792, AGN, SAA-III, 3 Alcabalas, leg.77, fs.122r.; Cartagena. Libro real, común y general de aduana y alcabalas, 1795, AGN, SAA-III, 1 Aduanas, leg.7, fs.1r.-116v.
} 
Real y otros empezaron a comprarlos en la ciudad y los destinaron a trabajar en sus haciendas ${ }^{83}$.

En los inmediatos alrededores de la plaza fuerte las mayores concentraciones de esclavos de propiedad particular habían estado en las haciendas, ladrilleras y tejares, los que habían pertenecido a la congregación religiosa de los Jesuitas, expulsada del imperio en 1767. Según los inventarios de tres de los seis tejares realizados en 1770, Tierra Bomba tenía 127 esclavos, Alcibia 110 y Preceptor 65 (total: 302$)^{84}$. Dos años más tarde las cantidades de esclavos Alcibia y Preceptor habían disminuido a 58 y 52 respectivamente $^{85}$, y para 1777 los seis tejares solo tenían 195 esclavos. Y el padrón de ese año de esos alrededores contabilizó un total de 263 esclavos $^{86}$. Muchos de estos esclavos fueron trasladados a la ciudad, y luego fueron adquiridos por propietarios de haciendas de los alrededores del Canal del Dique.

En cuanto a los esclavos del rey los cálculos económicos siempre habían hablado a favor del empleo de la mano de obra esclavizada en las fortificaciones porque representaban una menor inversión en comparación con la mano de obra libre. El ingeniero cartagenero Antonio de Narváez y la Torre en informe escrito en 1778 expresó las razones sobre el por qué se prefería el trabajo de los esclavos de particulares en varios frentes de la economía, en especial en las haciendas: la resistencia al clima, la fortaleza, el fácil control, “[...] y no ganando jornal, ni causando otro gasto, después del primero de su compra que el de su manutención, y vestuario, que es muy limitado hacen los trabajos mucho menos costosos, y por consiguiente mucho más útiles" 87 . En 1769, en el proyecto para construir la escollera submarina para cerrar la Bocagrande, con un valor total de 1.245.150 pesos, Antonio de Arévalo previó que los gastos en mano de obra y por concepto de otros rubros que no especificó, representaban de conjunto solo el $2,4 \%$ del costo total ${ }^{88}$.

Y si tomamos los 232 esclavos del rey de 1756, que recibían una ración de real y medio/día, (sin tener en cuenta que a los enfermos e inválidos se les daba una ración menor), al mes la erogación era de 1.305 pesos. Pero la misma cantidad de jornaleros, ganando el jornal de base de ese año (dos y medio reales/día), representaban un gasto de 2.175 pesos, un $67 \%$ más del costo de los esclavos ${ }^{89}$.

Si la mano de obra esclava salía más barata que la libre, entonces ¿por qué la corona no optó por comprar más esclavos? Juan Herrera y Sotomayor, el ingeniero que sentó las bases para la reconstrucción y construcción de las

\footnotetext{
${ }^{83}$ Cartagena. Receptoría. Libro real de cargo, 1804-1805, AGN, SAA-III, 3 Alcabalas, leg.86, fs.1r.-175r.

${ }^{84}$ AGN, SC, fondo Temporalidades, t.3, doc.12, fs.605r.-610v., 660r.-663v., 699r.-708v.

${ }^{85}$ A. Meisel "Esclavitud, mestizaje y hacienda en la provincia de Cartagena 1533-1851", p. 95.

${ }^{86}$ AGN, SC, fondo Lazaretos, t.1, doc.36, fs.920r.-929v.; AGN, SC, CVD, t.8, doc.59, fs.840r.-845r.

87 Antonio Narváez y la Torre, "Provincia de Santa Marta y Riohacha del Virreinato de Santa Fe [1778]", en Escritos económicos. Antonio de Narváez José Ignacio de Pombo, Bogotá, Banco de la República, 2010, pp. 38-40.

${ }^{88}$ Antonio de Arévalo, "Proyecto de cerrar la abertura de Bocagrande y resguardar las murallas del Norte de Cartagena de Indias, por D. Antonio de Arévalo, 1769”, en Antonio B. Cuervo, Colección de documentos inéditos sobre la geografía y la historia de Colombia, tomo I, Bogotá, Imp. de Vapor de Zalamea Hermanos, 1891-1894, p. 246.

${ }^{89}$ AGN, SAA-I, GM, caja 7, carpeta 17, fs.416r.-520r.; AGN, SC, Mejoras Materiales, t.20, doc.13, f.966r.
} 
obras de fortificaciones de Cartagena a lo largo del siglo XVIII, era partidario de emplear a trabajadores libres, arguyendo un criterio racionalidad. En 1721, planificando las obras pensaba que con el número de esclavos bozales que había y debido a que había que hacerlos ladinos (enseñarles el idioma, religión, sumisión) y que aprendieran los oficios, los trabajos se prolongarían y al final saldría más costosos. Según sus cálculos, aunque el jornal de los trabajadores libres representaba una mayor erogación que la ración reconocida a cada esclavo, el tiempo se reduciría y al final el costo sería menor ${ }^{90}$.

Pero más allá de esa polémica, los ingenieros que estuvieron al frente de las obras eran partidarios del trabajo de los esclavos, y pese a sus deseos las cifras indican que aquellos decrecieron mientras que aumentaron las de trabajadores libres y de presos forzados. Esa relación inversa se explica por varias razones.

Porque era un recurso al que se echaba mano en momento de apremios económicos y se enviaban a trabajar a otras ciudades fortificadas o se les vendían. Y cuando la premura de la obra era de importancia para la defensa de la ciudad, disponiéndose de mayores recursos económicos, y cuando la naturaleza de la obra pasaba a fases que requerían de trabajos especializados con base en nuevos materiales (hierro, madera, piedra tallada), podía producirse una modificación en las proporciones de empleo de mano de obra esclavizada y la libre. Por ejemplo, en 1756 se invirtió la relación en el empleo de trabajadores libres y esclavos gracias a que la disponibilidad de presupuesto, el apremio y la envergadura de las obras que se adelantaban obligó a vincular a trabajadores ${ }^{91}$.

Para 1756 se habían invertido las proporciones entre esclavos y presos por una parte y los trabajadores libres por otra: por cada esclavo trabajaban 3 libres, y por cada preso había 6 libres (ver gráfico 1). Y en diciembre de 1788 solo quedaban 78 esclavos y 98 desterrados. El ingeniero achacaba esas disminuciones,

... por haber cumplido unos [las penas los presos], muertos otros, y dado otros destinos a algunos, siendo mucha parte de ellos de muy pocos servicios por viejos y achacosos. Cuya falta se ha suplido con jornaleros voluntarios de 2, 3 y 4 reales de jornal (que en el día solo hay en la cantera y Bocagrande 111) resultando de esto el aumento de un crecido costo que se hubiera evitado con negros y forzados, sin otros varios gastos que se han ocasionado y no se pudieron incluir en $\mathrm{el}^{92}$.

${ }^{90}$ AGI, Santa Fe, leg. 472

${ }^{91}$ AGN, SAA-I, GM, caja 7, carpeta 17, f.513r.

${ }^{92}$ AGS, SEDG, leg.7236, exp.9, fs.66r.-69r. 


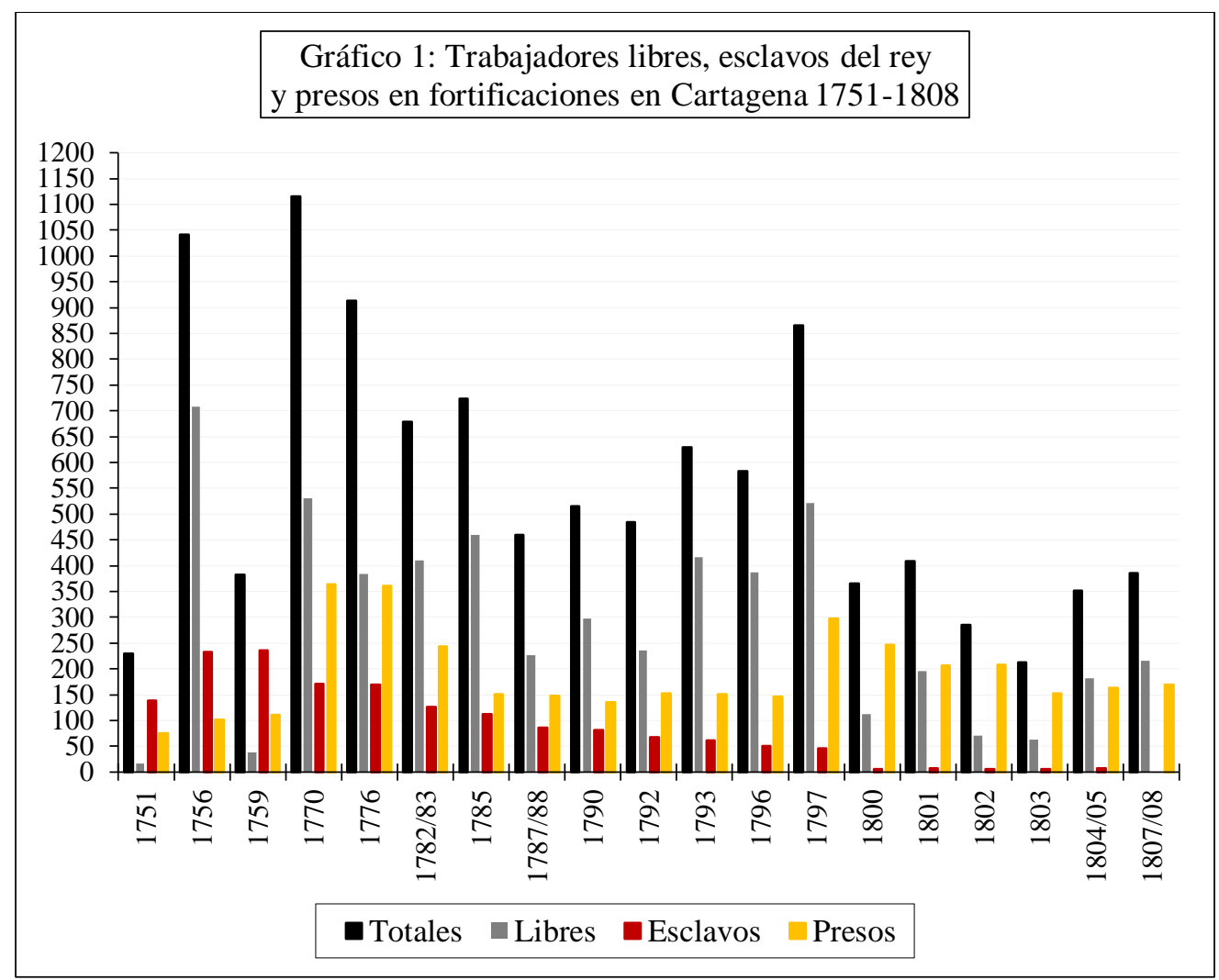

Fuente: tomado de S. P. Solano, "Trabajadores, jornales, carestía y crisis política en Cartagena de Indias", 555.

Varios motivos explican las significativas diferencias en el empleo de mano de obra servil y forzada y trabajadores libres. Uno era la disponibilidad de presupuestos. Otro tuvo que ver con las distintas fases de construcción de las obras. Y también con la oferta de mano de obra. A escaso presupuesto se empleaba un mayor número de esclavos y presos. Y cuando las asignaciones presupuestales eran más abundantes se incrementaba el empleo de mano de obra libre. Asimismo, los meses iniciales de cada año, al ser más generosos en la disponibilidad de presupuesto, permitían una mayor contratación de libres. Pero con el transcurso del año y con la disminución de los flujos presupuestales, esa contratación disminuía y aumentaba el empleo de esclavos y presos.

El empleo de trabajadores libres también fue una realidad gracias a que hubo mayor disponibilidad de hombres dispuestos a trabajar en las obras, tanto por el crecimiento de la población de la ciudad, como por migraciones estacionales. Para mediados del XVIII la población no era suficiente para proveer la mano de obra necesaria en las baterías de San José, fuerte de San Fernando de Bocachica y fuerte de San Sebastián del Pastelillo luego de las destrucciones que sufrieron en 1741 por el asedio de la armada inglesa, como también el cierre de la Bocagrande mediante una escollera submarina. Según un padrón eclesiástico realizado en 1751 la ciudad contaba con 7.796 almas 
de confesión, sin incluir al batallón de Pie Fijo ${ }^{93}$, cifra que apenas representa la mitad del total de los habitantes que arrojó el padrón de 1777. En 1750 Ignacio Sala, ingeniero y gobernador de Cartagena y su provincia, informaba a Madrid que había dificultades para continuar con los trabajos del cierre de Bocagrande debido, entre otros factores, a la falta de operarios ${ }^{94}$. Este último problema se afrontó trayendo personal de las inmediaciones de Cartagena, de otras provincias y del valle del rio Magdalena, mediante el envío de emisarios para reclutar trabajadores. En 1755, cuando se contó con un presupuesto generoso solo para los trabajos en las fortificaciones de Bocachica, creció el número de trabajadores gracias a la llegada de peones, albañiles y canteros provenientes de los resguardos indígenas de la provincia de Cartagena, de la jurisdicción de Mompox y aún de las provincias andinas neogranadinas. En mayo de ese año se contaba con 604 trabajadores entre esclavos, presos y voluntarios; un mes más tarde esa cantidad subió a 841 y a finales de julio la cifra llegó a los 1.243 operarios $^{95}$.

Pero también tenía que ver con el hecho de que la oferta de esclavos y presos era inelástica, mientras que la de trabajadores libres podía incrementarse con el sector de artesanos y jornaleros que vivían en la ciudad y gracias a los flujos laborales estacionales de las comarcas inmediatas y desde lejanas. Esa relación entre esclavos del rey, trabajadores libres y presos forzados ha sido motivo de un reciente análisis a propósito de la mano de obra en los sistemas defensivos de Cartagena de Indias) ${ }^{96}$. Lo indica ese estudio es que al lado de los trabajadores libres se emplearon esclavos de propiedad del rey y presos, en su mayoría destinados a las labores de extracción de piedras en las canteras de Caño Loro, Albornoz, Tesca y los Morros (Manzanillo), a la elaboración de cal, ladrillos y tejas ${ }^{97}$ y en los duros trabajos de la construcción de la escollera submarina de Bocagrande. En ese frente laboral la tendencia fue de crecimiento del empleo de trabajadores libres, la caída del número de esclavos del rey y el incremento del empleo de presos. Al parecer durante los siglos XVI, XVII y primera mitad del XVIII se había acudido a los esclavos del rey, a los desterrados condenados a trabajos forzados para aminorar los gastos representados por la contratación de mano de obra libre. Había sido menor el empleo de trabajadores libres. Pero para la segunda mitad del XVIII buena parte de los trabajos lo realizaron trabajadores libres y presos.

Para el último tercio del siglo XVIII también decayó la participación de los esclavos del rey en las obras de fortificaciones como lo hemos registrado en la tabla 4, en la que se observa que la caída de la cifra se dio a finales del decenio de 1780 sin que aún tengamos suficiente claridad sobre sus causas. Si hemos logrado constatar que en 1789 el virrey Antonio Caballero y

\footnotetext{
${ }^{93}$ AGI, Santa Fe, 1023.

${ }^{94}$ AGN, SC, fondo Competencias-Bolívar y Panamá, t.2, doc.18, fs.609r.-v.

${ }^{95}$ AGN, SC, fondo Virreyes, t.11, doc.50, f.1070v.; AGN, SC, MM, t.67, doc.146, fs.950r.-967r.; AGN, SAA I-16, GM, leg.26, carpeta 6, fs.607v.-609v.; AGN, SC, MM, t.121, doc.23, fs.313r.-314v.; t.61, doc.162, fs.944r.-962r.; AGN, SAA I16, GM, leg.2, carpeta 20, f.740r.; AGN, SC, Mejoras Materiales, t.20, doc.13, f.968v.

${ }^{96}$ S. P. Solano, "Trabajadores, jornales, carestía y crisis política en Cartagena de Indias", 549-588.

${ }^{97}$ AGN, SC, Lazaretos, t.1, doc.36, fs.920r.-929v.; AGN, SC, Temporalidades, t.11, doc.20, fs.956r.-987v.; doc.21, fs.988r.1008v.; t.3, doc.8, fs.208r.-272r.; AGN, SC, Curas y Obispos, t.3, doc.10, fs.909r.-937v.
} 
Góngora ordenó desplazar a un número significativo de esclavos del rey proveniente de distintos puntos con destino al Chocó, para ser vendidos allí pues las minas de oro estaban demandando mano de obra debido a que se había cerrado los circuitos internacionales de aprovisionamiento de esclavizados 98 .

La mano de obra esclavizada empezó a ser reemplazada por un contingente de presos oriundo de diferentes latitudes que eran enviado a Cartagena a cumplir las penas de destierro y de trabajo forzado, laborando en las fortificaciones y en las canteras de la ciudad ${ }^{99}$. Durante el último cuarto del XVIII ascendió el número de estos gracias al incremento del número de desterrados que provenían de diferentes áreas del virreinato neogranadino. Entre 1749 y 1760 (no contando con información para 6 años) se enviaron a Cartagena a 191 presos, en su mayoría de las provincias de los Andes neogranadinos, para que cumplieran sus castigos en los trabajos de las fortificaciones y solo recibiendo la ración diaria de alimentos (real y medio por día). Y entre 1768 y 1807 (faltando datos para 22 años) se trajo un total de 544 reos desterrados de sus lugares de viviendas. En total en los 23 años de los que tenemos información correspondiente al periodo comprendido entre 1749 y 1807 , se enviaron a Cartagena 735 reos para un promedio de 31 presos por año ${ }^{100}$. Para el primer decenio del siglo XIX el número de presos en los trabajos de fortificaciones sobrepasó al de libres, lo que se debió a que la guerra con Inglaterra obligó a aplicar ajustes fiscales, y para las arcas reales, que tenía que mantener a los presos, estos eran más rentables que los hombres libres, pues mientras que el gasto en la ración diaria de los primeros se mantuvo estable durante todo el siglo XVIII en real y medio, el de los peones libres eran el doble y muchas veces más. Además, el gasto de la vigilancia de los presos era obviada al ponerlos a trabajar al lado de los esclavos del rey, aprovechando a los guardias para controlar a ambos contingentes de trabajadores. A finales de noviembre de 1797 se autorizaba al ingeniero Antonio de Arévalo a continuar con los trabajos de recomponer la parte de la escollera submarina de la Bocagrande derrumbada por el intenso oleaje producido por un fuerte vendaval, “[...] siempre que no se empleen más peones y trabajadores, que los esclavos del rey y los forzados porque no hay caudales con que concurrir a mayores gastos $[\ldots]$ "101.

La relación inversa entre el decrecimiento de la cantidad de esclavos que trabajaban en las fortificaciones y el incremento del trabajo de los libres era expresión de los cambios que se operaron en las relaciones socio-raciales de la ciudad, del crecimiento de la población libre catalogada como las castas con relación al total de esclavos, como también del total de libres (blancos y de las castas) en detrimento del total de los blancos. Cuando comparamos las cifras de los censos de 1663, 1751 y 1777 y en los datos proporcionados por Joaquín Francisco Fidalgo, jefe de la Expedición Hidrográfica de Costas,

\footnotetext{
${ }^{98}$ AGN, SAA I-16, GM, leg.56, carpeta 1, fs.1r.-10r.

${ }^{99}$ S. P. Solano, "Trabajadores, jornales, carestía y crisis política en Cartagena de Indias", 549-588.

${ }^{100}$ S. P. Solano, "Trabajadores, jornales, carestía y crisis política en Cartagena de Indias", 549-588.

${ }^{101}$ AGN, SC, Mejoras Materiales, t.20, doc.13, f.966r.
} 
quien vivió en Cartagena entre 1792 y 1810, se observa las transformaciones acaecidas en la composición del estatus y socio-racial de sus habitantes, perdiendo representatividad la esclavitud con relación al total de los libres, en especial con el aumento del número de los libres de todos los colores. En 1663 la relación libres-esclavos era casi pareja al existir 2 libres por 1 esclavo ${ }^{102}$. Para 1751, cuando un censo eclesiástico contabilizó 7.856 almas de confesión, sin incluir al batallón de pie Fijo ${ }^{103}$, los libres eran 6.194 personas (incluyendo a los blancos), y los esclavos $1.602^{104}$, lo que arroja una proporción de 4 libres por 1 esclavo, relación que se mantuvo igual en el censo de 1777. Y por las cifras de Joaquín Francisco Fidalgo ${ }^{105}$ se infiere que esa proporción pasó a 9 libres por 1 . Si en 1663 por cada tres blancos había un libre de las castas, para 1777 la relación se había invertido y por cada 2 libres de las castas había 1 blanco, y para 1805 era de 8 a 1 .

\section{Conclusiones}

Por su condición de plaza fuerte que desempeñaba funciones de primer orden en la defensa militar del imperio, en Cartagena de Indias, además de los esclavos de propiedad de particulares existían los que pertenecían a la corona. Los primeros representaban recursos económicos y prestancia social para sus propietarios, y debido a la dinámica adquirida por la vida económica, social y socio-racial de la ciudad durante la segunda mitad del siglo XVIII distintos sectores sociales participación en la posesión de esclavizados, lo que, a su vez, se expresaba en la presencia de estos por toda la ciudad, el acceso al ejercicio de oficios y los niveles de autonomía que lograban en los usos que hacían de los espacios públicos. Los esclavos de la corona casi siempre eran bozales, padecían controles más rígidos por parte de los sobrestantes de las fortificaciones que eran los encargados de vigilarlos, y en los trabajos que desempeñaban en las canteras, hornos y fortificaciones tenían vigilancias para evitar huidas. Al parecer las relaciones entre ambos contingentes de esclavizados no eran conflictivas si las medimos por sus uniones conyugales registradas en el censo de 1777 del barrio de Santo Toribio. Y es posible que ambos sectores participaran en los cabildos de castas.

Aunque continuaron acudiendo al cimarronaje en busca de libertad, la destrucción de muchos palenques que habían surgidos en los siglos XVI y XVII y la negociación entablada por los que sobrevivieron con las autoridades coloniales, implicó acudir a nuevos recursos por parte de los esclavos para intentar aminorar sus difíciles condiciones de vida. Los trabajos por fuera de las casas de los amos, el acceso a espacios abiertos en los que ejercían controles sobre sus trabajos, cuerpos y tiempos, los pequeños ingresos económicos, y acudir a la justicia para demandar protección, fueron aspectos que de alguna manera incidieron en las relaciones con sus amos y las autoridades. Aunque muchos continuaron viviendo en las casas de sus

\footnotetext{
${ }^{102}$ AGI, Santa Fe, leg.43, R.4, N.19, f.1r.

${ }^{103}$ AGN, SAA I-16, GM, leg.6, carpeta 6, fs.479r.-502r.

104 AGI, Santa Fe, leg. 1023.

105 J. F. Fidalgo, Derrotero y cartografía de la Expedición Fidalgo por el Caribe neogranadino, p. 118.
} 
propietarios, otros llegaron a vivir de forma independiente, hecho que evidencia cierta flexibilización en la relación amo-esclavos en lo que atañe la circulación de estos en la espacialidad de la ciudad.

Durante el periodo estudiado la esclavitud mostraba una tendencia decreciente en Cartagena, expresada en un descenso del número de esclavos y en su disminución en el total de la población de la ciudad. Aunque como contrapartida aumentó la representatividad de los libres de color, los que dominaron la vida social y laboral de la ciudad, y pese a que la esclavitud era un hecho menor en la ciudad, sus consecuencias sociales y culturales continuaron marcando la forma como estaba ordenada la sociedad. Además, la disminución del riesgo de la rebelión y del cimarronaje que se había traducido en palenques, es posibles que se aflojaran los mecanismos de control sobre los esclavos, y que estos, a su manera, se apropiaran del espacio urbano. Y también desarrollaron mecanismos de resistencia, transgresión y negociación aún dentro de las onerosas condiciones que les negaba la libertad y el ser sujetos de plenos derechos.

\section{Bibliografía}

\section{Fuentes primarias:}

Archivo General de la Nación-Colombia (AGN), Sección Colonia (SC), fondos: Abastos; Aduanas; Censos Varios Departamentos (CVD); Competencias-Bolívar y Panamá; Curas y Obispos; Empleados Públicos-Bolívar; Historia Civil; Juicios Criminales; Lazaretos; Mejoras Materiales; Milicias y Marina (MM); Miscelánea; Negros y Esclavos-Bolívar; Negros y Esclavos-Panamá; Real Audiencia, BolívarVenezuela; Temporalidades; Virreyes.

AGN, Sección Archivos Anexos (SAA) grupo I, fondos: 12, Empréstitos; 16 Guerra y Marina (GM); 17 Historia; grupo III, fondos: 1 Aduanas; 3 Alcabalas.

Archivo General de Indias (AGI), Santa Fe.

Archivo General de Simancas-España, Secretaría de Estado y Despacho de Guerra (AGS, SEDG).

Archivo Histórico Nacional de Madrid, Códices.

Anguiano, Manuel de, "Descripción histórica de la provincia de Cartagena de Indias", en Servicio Geográfico del Ejército (España), Depósito de la Guerra, Archivo de Planos, Estante J, Tabla 5, Cartera 2a , Sección a, No. 7, 1805.

Arévalo, Antonio de, "Proyecto de cerrar la abertura de Bocagrande y resguardar las murallas del Norte de Cartagena de Indias, por D. Antonio de Arévalo, 1769", en Antonio B. Cuervo, Colección de documentos inéditos sobre la geografía y la historia de Colombia, tomo I, Bogotá, Imp. de Vapor de Zalamea Hermanos.1891-1894, pp. 221-248.

Cartografía y relaciones históricas de ultramar, t. 5, Madrid, Servicio Histórico Militar, 1980. 
Durán y Díaz, Joaquín, Estado general de todo el virreinato de Santafe de Bogotá, Bogotá, Banco de la República 1794.

"El deber de vivir ordenadamente y de obedecer al rey". Anuario Colombiano de Historia Social y de la Cultura, 20, 1992: 109-131.

Fidalgo, Joaquín Francisco, Derrotero y cartografía de la Expedición Fidalgo por el Caribe neogranadino (1792-1810). Bogotá: El Áncora Eds., 2012.

Lucena Salmoral, Manuel, Leyes para esclavos. El ordenamiento jurídico sobre la condición, tratamiento, defensa y represión de los esclavos en las colonias de la América española, Madrid, Fundación Larramendi, 2000.

Juan, Jorge y Ulloa, Antonio de, Relación histórica de un viaje a la América Meridional, parte primera, tomo primero, Madrid, Imp. de Antonio Marín, 1748.

Narváez y la Torre, Antonio, "Provincia de Santa Marta y Riohacha del Virreinato de Santa Fe [1778]", en Escritos económicos. Antonio de Narváez José Ignacio de Pombo, Bogotá, Banco de la República, 2010, pp. 22-69.

Urueta, José P., Documentos para la historia de Cartagena, tomo 1, Cartagena, Tip. de A. Araujo, 1887.

\section{Fuentes secundarias:}

Aguilera, María y Meisel, Adolfo, Tres siglos de historia demográfica de Cartagena, Cartagena, Banco de la República, 2009.

Anrup, Roland y Chaves, María E., "La "plebe" en una sociedad de "todos los colores". La construcción de un imaginario social y político en la colonia tardía en Cartagena y Guayaquil”. Cahiers du Monde Hispanique et Luso-Brésilien, 84, 2005: 93-126.

Anrup, Roland y Pérez, Angélica, "De la hostia a la horca: el delito de un mulato en Cartagena de Indias del siglo XVIII". Anales, 1, 1998: 55-90.

Arrelucea, Maribel, Replanteando la esclavitud. Estudios de etnicidad y género en Lima borbónica, Lima, Centro de Desarrollo Étnico/Centro Cultural España, 2009.

Avendaño, Fanny, Vías legales usadas por los esclavos en la colonia para pedir la libertad. Un estudio de casos, 1791-1803, Cartagena, trabajo de grado en HistoriaUniversidad de Cartagena, 2017.

Barona, Guido, “Ausencia y presencia del 'negro' en la historia de Colombia”. Memoria y Sociedad, 1, (1), 2014: 77-105.

Bernard, Carmen, Negros esclavos y libres en las ciudades hispanoamericanas, Madrid, Fundación Larramendi/Mapfre, 2005.

Borrego, María del C., Palenques de negros en Cartagena de Indias a fines del siglo XVII, Sevilla, EEHA/CSIC, 1973.

Borrego, María del C., Cartagena de Indias. La andadura de una vida bajo la colonia, Bogotá, El Áncora Eds., 2010. 
Conde, Jorge, "Negros sublevados, justicias y hacendados en la Provincia de Santa Marta en la segunda mitad del siglo XVIII", en Edgard Rey Sinning (comp.), Santa Marta en el siglo XVIII. Tertulia Samaria. Tomo I, Santa Marta, CAJAMAG, 2018, pp. 159175.

Chaves, María E., "Paternalismo, iluminismo y libertad. La vigencia de la Instrucción esclavista de 1789 y su impacto en la sociedad colonial". Historia y Sociedad, 11, 2011: 69-93.

Garrido, Margarita, "Vida cotidiana en Cartagena de Indias en el siglo XVII", en Haroldo Calvo y Adolfo Meisel (eds.), Cartagena de Indias en el siglo XVII, Cartagena, Banco de la República, 2007, pp. 451-498.

Giolitto, Loredana, "Esclavitud y libertad en Cartagena de Indias. Reflexiones en torno a un caso de manumisión a finales del período colonial". Fronteras de la Historia, 8, 2003: 63-91.

Giraldo, Carolina, "Esclavos sodomitas en Cartagena colonial. Hablando del pecado nefando". Historia Crítica, 20, 2001: 171-178.

Gutiérrez, Ildefonso, "El comercio y mercado de negros esclavos en Cartagena de Indias (1533-1850)". Quinto Centenario, 12, 1987: 187-210.

Helg, Aline, "Esclavos y libres de color, negros y mulatos en la investigación y la historia de Colombia". Revista Iberoamericana, LXV, (188-189), 1999: 697-712.

Helg, Aline, "Sociedad y raza en Cartagena a fines del siglo XVIII", Haroldo Calvo y Adolfo Meisel (eds.), Cartagena de Indias en el siglo XVIII, Cartagena, Banco de la República, 2005, pp. 319-364.

Helg, Aline, "Oralidad y escritura en la historiografía de los esclavos afrodescendientes". En Graciela Maglia y Armin Schwegler (eds.), Palenque. Colombia: Oralidad, identidad y resistencia, Bogotá, Universidad Javeriana, 2011, pp. 85-106.

Helg, Aline, ¡Nunca más esclavos!: una historia comparada de los esclavos que se liberaron en las Américas, Bogotá, Banco de la República/FCE, 2018.

Hernández, Dianis, Esclavos y esclavas en el acceso a la libertad en Cartagena y Mompox 1759-1794: proporciones y dinámicas, Cartagena, trabajo de grado en Historia-Universidad de Cartagena, 2014.

Jaramillo Uribe, Jaime, "Esclavos y señores en la sociedad colombiana del siglo XVIII". Anuario Colombiano de Historia Social y de la Cultura, 1, 1963: 3-62.

Kuethe, Allan, Reforma militar y sociedad en la Nueva Granada, 1773-1808, Bogotá, Banco de la República, 1993.

Landers, Jane, "The African landscape of 17th century Cartagena and its hinterlands", in Jorge Cañizares-Ezguerra, James Sidbury and Matt D. Childs (eds.), The Black Urban Atlantic in the Age of the Slave Trade The Early Modern Americas, Philadelphia, University of Pennsylvania Press, 2013, pp. 147-162.

Marchena, Juan, La institución militar de Cartagena de Indias 1700-1810, Sevilla, EEHA/CSIC, 1982. 
Marichal, Carlos, La bancarrota del virreinato. Nueva España y las finanzas del imperio español (1780-1810), México, FCE/COLMEX, 1999.

Maya, Luz A., "Paula de Eguiluz y el arte del bien querer. Apuntes para el estudio del cimarronaje femenino en el Caribe, siglo XVII". Historia Crítica, 24, 2002: 101-118.

McFarlane, Anthony, "Cimarrones y palenques en Colombia siglo XVIII". Historia y Espacio, 14, 1991: 53-78.

McFarlane, Anthony, "Autoridad y poder en Cartagena de Indias: la herencia de los Austrias", en Haroldo Calvo y Adolfo Meisel (eds.), Cartagena de Indias en el siglo XVIII, Cartagena, Banco de la República, 2005, pp. 221-259.

Meisel, Adolfo, "Esclavitud, mestizaje y hacienda en la provincia de Cartagena 15331851", en Gustavo Bell (ed.), El Caribe colombiano, Barranquilla, Universidad del Norte, 1988, pp. 69-137.

Meisel, Adolfo, "El situado de Cartagena de Indias a fines del Siglo de las Luces", en Carlos Marichal y Johanna von Grafenstein (coords.), El secreto del imperio español: los situados coloniales en el siglo XVIII, México, COLMEX/Instituto Mora, 2012, pp. 193-211.

Múnera, Alfonso, Fronteras imaginadas, Bogotá, Planeta, 2005.

Navarrete, María C., "Los artesanos negros en la sociedad cartagenera del siglo XVII". Historia y Espacio, 15, 1994: 7-25.

Navarrete, María C., Génesis y desarrollo de la esclavitud en Colombia, Cali, Universidad del Valle, 2005.

Navarrete, María C., San Basilio de Palenque, memoria y tradición. Surgimiento y avatares de las gestas cimarronas en el Caribe colombiano, Cali, Universidad del Valle, 2008.

Palacios, Jorge, La trata de negros por Cartagena de Indias: 1650-1750, Tunja, UPTC, 1973.

Pérez, Francisco, "Modo de vida de esclavos y forzados en las fortificaciones de Cuba: siglo XVIII". Anuario de Estudios Americanos, 47, 1990: 241-257.

Rangel, Fanny, Entre la libertad y la esclavitud: "Dominga Pérez en el litigio por su libertad y la de sus hijas, Cartagena, trabajo de grado en Historia-Universidad de Cartagena 2011.

Ripoll, María T., La elite en Cartagena y su tránsito a la República. Revolución política sin renovación social, Bogotá, Universidad de los Andes, 2006.

Romero, Dolcey, Los afroatlanticenses: esclavización, resistencia y abolición, Barranquilla, Universidad Simón Bolívar, 2009.

Romero, Dolcey, "Los acuerdos y la idealización del palenque en la provincia de Cartagena: el caso del Totumo (1714-1767)". Historia Caribe, 15 (37), 2020: 215247. 
Romero, Dolcey, "Cimarrones y palenques en el actual departamento del Atlántico. El caso de tabacal: resistencias y exclusión”. Amauta, 19, (37), 2021: 1-23.

Romero, Dolcey, Márquez, Rosario y García, Manuel, Manumisión y abolición de la esclavitud en el Caribe colombiano 1812-1852, Barranquilla, Universidad Simón Bolívar, 2018.

Ruiz Rivera, Julián, "Gobierno, comercio y sociedad en Cartagena de Indias en el siglo XVII", en Haroldo Calvo y Adolfo Meisel (eds.), Cartagena de Indias en el siglo XVII, Cartagena, Banco de la República, 2007, pp. 353-376.

Saguier, Eduardo, "La naturaleza estipendiaria de la esclavitud urbana colonial. El caso de Buenos Aires en el siglo XVIII". Estudos Ibero-Americanos, 15, (2), 1989: 315325 .

Sánchez, David, La esclavitud y sus conceptos en Cartagena de Indias (1789-1797), Cartagena, trabajo de grado en Historia-Universidad de Cartagena, 2017.

Serrano, José, Fortificaciones y tropas. El gasto militar en Tierra Firme, 1700-1788, Bogotá, El Áncora Eds., 2006.

Solano, Sergio Paolo, "Artesanos, jornaleros y formas concentradas de trabajo: el Apostadero de la Marina de Cartagena de Indias (Nuevo Reino de Granada) en el tránsito entre los siglos XVIII y XIX”. Theomai, 31, 2015: 79-115.

Solano, Sergio Paolo, "Pedro Romero, el artesano: trabajo, raza y diferenciación social en Cartagena de Indias a finales del dominio colonial". Historia Crítica, 61, 2016: 151-170.

Solano, Sergio Paolo, "Artesanos, bellas artes, raza y política en Cartagena de Indias (Nuevo Reino de Granada) a finales de la colonia", en Alcides Beretta Curi (coord.), Inmigración europea, artesanado y orígenes de la industria en América Latina, Montevideo, Universidad de la República, 2016, pp. 113-142.

Solano, Sergio Paolo, "Trabajadores, jornales, carestía y crisis política en Cartagena de Indias, 1750-1810”. Historia, 51, (II), 2018: 549-588.

Solano, Sergio Paolo, "Gasto fiscal e inversiones en mano de obra libre en Hispanoamérica. el caso de Cartagena de Indias (1750-1810)". Anuario de Historia Regional y de las Fronteras, 24, (2), 2019: 195-232.

Solano, Sergio Paolo, "Artesanos de color y milicias en el Caribe continental hispánico. Reflexiones acerca de la cultura política de los libres de color a finales del dominio colonial”, en Alcides Beretta Curi (coord.), Artesanos de dos mundos: diálogos y problemas de investigación, Montevideo, Universidad de la República, 2019, pp. 753.

Solano, Sergio Paolo, “Trabajadores, salarios y precios en Cartagena de Indias, 17501810. Una aproximación al estudio del mundo laboral de la plaza fuerte". Boletín de Historia y Antigüedades, CVI, (869), 2019: 83-129.

Solano, Sergio Paolo, "El costo social de la república: los trabajadores de los sistemas defensivos de Cartagena de Indias, 1750-1850”. Historia y Memoria, 18, 2019: 243287. 
Solano, Sergio Paolo, Vanegas Beltrán, Muriel y Flórez Bolívar, Roicer, "Sociedad, raza, educación y movilidad social: Colegio Real y Seminario Conciliar San Carlos Borromeo y Sacerdotes en Cartagena de Indias (1750-1810)". Historia, 53, (II), 2020: 631-660.

Solano, Sergio Paolo, Vanegas Beltrán, Muriel y Torres, Johan, "Tabaco y trabajo femenino. La Real Fábrica de Cigarros de Cartagena de Indias, 1778-1805". Memorias, 17, (45), 2021. Próximo a publicarse.

Taborda, Sandra, La esclavitud en Cartagena en la segunda mitad del siglo XVIII: entre el maltrato y la resistencia, Cartagena, trabajo de grado en Historia-Universidad de Cartagena 2013.

Torres, Rafael, El precio de la guerra. El Estado fiscal militar de Carlos III(1779-1783), Madrid, Marcial Pons, 2013.

Tovar, Hermes, Grandes empresas agrícolas y ganaderas, Bogotá, CIEC, 1980.

Vanegas Beltrán, Muriel, Solano, Sergio Paolo y Flórez, Roicer, "Elites y poder colonial: comerciantes y cabildo en Cartagena de Indias, 1750-1810". Memorias, 16, (42), 2020: 44-75.

Vanegas Beltrán, Muriel, Solano, Sergio Paolo y Cruz, Maribel de la, "El pequeño comercio en Cartagena de Indias: las tiendas de pulperías, 1770-1810". Amauta, 19, (37), 2021: 1-23.

Velásquez, Rogelio, "Gentilicios africanos del occidente de Colombia". Revista Colombiana de Folclor, II, (7), 1962: 107-148.

Vidal, Antonino, Cartagena de Indias y la región histórica del Caribe, 1580-1640, Sevilla, CSIC/EEHA/Universidad de Sevilla, 2002. 